medRxiv preprint doi: https://doi.org/10.1101/2020.06.09.20126979; this version posted June 11, 2020. The copyright holder for this preprint (which was not certified by peer review) is the author/funder, who has granted medRxiv a license to display the preprint in perpetuity.

It is made available under a CC-BY 4.0 International license .

\title{
Child wasting and concurrent stunting in low- and middle-income countries
} Andrew Mertens, ${ }^{1 *}$ Jade Benjamin-Chung, ${ }^{1}$ John M Colford Jr, ${ }^{1}$ Alan E Hubbard, ${ }^{1}$ Mark J van der Laan, ${ }^{1}$ Jeremy Coyle ${ }^{1}$, Oleg Sofrygin, ${ }^{1}$ Wilson Cai, ${ }^{1}$ Wendy Jilek, ${ }^{1}$ Sonali Dayal, ${ }^{1}$ Anna Nguyen, ${ }^{1}$ Nolan N Pokpongkiat, ${ }^{1}$ Stephanie Djajadi, ${ }^{1}$ Anmol Seth, ${ }^{1}$ Esther O Chung, ${ }^{1}$ Ivana Malenica, ${ }^{1}$ Nima Hejazi, ${ }^{1}$ Haodong $\mathrm{Li}^{1}{ }^{1}$ Ryan Hafen, ${ }^{2}$ Vishak Subramoney, ${ }^{3}$ Jonas Häggström, ${ }^{4}$ Thea Norman, ${ }^{5}$ Parul Christian, ${ }^{6}$ Kenneth $\mathrm{H}$ Brown, ${ }^{7}$ Benjamin F. Arnold, ${ }^{1,8,9 *}$ and members of the ki Child Growth Consortium

${ }^{1}$ Division of Epidemiology \& Biostatistics, University of California, Berkeley, 2121 Berkeley Way Rm 5302 Berkeley, CA 94720-7360

${ }^{2}$ Hafen Consulting, LLC, West Richland WA, 99353

${ }^{3}$ Certara Canada, 2000 Peel St, Montreal, Quebec H3A 2W5, Canada

${ }^{4}$ MTEK Sciences 802-777 West Broadway, Vancouver, BC, V5Z 1J8, Canada

${ }^{5}$ Quantitative Sciences, Bill \& Melinda Gates Foundation, 500 5th Ave N, Seattle, WA 98109

${ }^{6}$ Maternal, Newborn \& Child Health Discovery \& Tools, Bill \& Melinda Gates Foundation, 500 5th Ave N, Seattle, WA 98109

${ }^{7}$ Department of Nutrition, University of California, Davis, 3135 Meyer Hall, Davis, CA 95616-5270

${ }^{8}$ Francis I. Proctor Foundation, University of California, San Francisco, 95 Kirkham St, San Francisco, CA 94143

${ }^{9}$ Department of Ophthalmology, University of California, San Francisco, 10 Koret Way, San Francisco, CA 94143

\footnotetext{
* Corresponding authors:
}

Andrew Mertens, amertens@berkeley.edu, Division of Epidemiology \& Biostatistics, University of California, Berkeley, 2121 Berkeley Way Rm 5302 Berkeley, CA 94720-7360

Benjamin F. Arnold, ben.arnold@ucsf.edu, Francis I. Proctor Foundation, University of California, San Francisco, 95 Kirkham St, San Francisco, CA 94143

\section{Abstract}

Acute malnutrition accounts for an immense disease burden and is implicated as a key, underlying cause of child mortality in low resource settings. Child wasting, defined as weight-for-length more than 2 standard deviations below international standards, is a leading indicator to measure the Sustainable Development Goal target to end malnutrition by 2030. Prevailing methods to measure wasting rely on cross-sectional surveys that are unable to measure onset, recovery, and persistence - key features of wasting epidemiology that could inform preventive interventions and disease burden estimates. Here, we show through an analysis of 18 longitudinal cohorts that child wasting is a highly dynamic process of incident onset and recovery, and that peak incidence is between birth and 3 months - far earlier than peak prevalence at 12-15 months. By age 24 months the proportion of children who had ever experienced a wasting episode (33\%) was more than 5 -fold higher than prevalence (6\%), suggesting that the wasting burden is likely far higher than cross-sectional surveys suggest. Seasonally driven changes in population mean weight-for-length were large ( $>0.5 \mathrm{z}$ in some cohorts) and were synchronous with rainfall across diverse settings, creating potential for seasonally targeted interventions. Our results motivate a new focus on extending preventive interventions for child wasting to pregnant and lactating mothers, and for preventive and therapeutic interventions to include children below age 6 months in addition to current targets of ages 6-59 months. 
medRxiv preprint doi: https://doi.org/10.1101/2020.06.09.20126979; this version posted June 11, 2020. The copyright holder for this preprint (which was not certified by peer review) is the author/funder, who has granted medRxiv a license to display the preprint in perpetuity.

It is made available under a CC-BY 4.0 International license.

Members of the ki Child Growth Consortium

47 1. Tahmeed Ahmed, International Centre for Diarrhoeal Disease Research, Bangladesh

$48 \quad 2 . \quad$ Asad Ali, Aga Khan University, Pakistan

49 3. France Begín, UNICEF, USA

50 4. Pascal Obong Bessong, HIV/AIDS \& Global Health Research Programme, University of Venda,

51 South Africa

$525 . \quad$ Robert E. Black, Johns Hopkins University, Bloomberg School of Public Health, USA

53 6. Ladaporn Bodhidatta, Armed Forces Research Institute of Medical Sciences, Thailand

54 7. William Checkley, Johns Hopkins University, School of Medicine, USA

55 8. Jean E. Crabtree, Leeds Institute for Medical Research, St. James's University Hospital, University

56 of Leeds, United Kingdom

57 9. Rina Das, International Centre for Diarrhoeal Disease Research, Bangladesh

58 10. Subhasish Das, International Centre for Diarrhoeal Disease Research, Bangladesh

59 11. Christopher P. Duggan, Center for Nutrition, Boston Children's Hospital, USA

60 12. Abu Syed Golam Faruque, International Centre for Diarrhoeal Disease Research, Bangladesh

61 13. Wafaie W. Fawzi, Department of Global Health and Population, Harvard TH Chan School of

62 Public Health, USA

63 14. José Quirino da Silva Filho, Federal University of Ceará, Brazil

64 15. Robert H. Gilman, Johns Hopkins University, Bloomberg School of Public Health, USA

65 16. Richard Guerrant, University of Virginia, USA

66 17. Rashidul Haque, International Centre for Diarrhoeal Disease Research, Bangladesh

67 18. Eric R. Houpt, University of Virginia, USA

68 19. Najeeha Talat Iqbal, Department of Pediatrics and Child Health, Aga Khan University, Pakistan

69 20. Jacob John, Christian Medical College, Vellore, Tamil Nadu, India

70 21. Sushil Matthew John, Professor, Low Cost Effective Care Unit, Christian Medical College, Vellore, 71 Tamil Nadu, India

72 22. Gagandeep Kang, Translational Health Science and Technology Institute, India

73 23. Margaret Kosek, University of Virginia, USA

74 24. Aldo Ângelo Moreira Lima, Federal University of Ceará, Brazil

75 25. Tjale Cloupas Mahopo, Department of Nutrition, School of Health Sciences, University of Venda, 76 South Africa

77 26. Dharma S. Manandhar, Mother and Infant Research Activities (MIRA), Nepal

78 27. Karim P. Manji, Department of Pediatrics and Child Health, Muhimbili University School of

79 Health and Allied Sciences, Tanzania

80 28. Estomih Mduma, Haydom Lutheran Hospital, Tanzania

81 29. Venkata Raghava Mohan, Professor, Community Medicine, Christian Medical College, Vellore,

82 Tamil Nadu, India

83 30. Sophie E. Moore, Department of Women and Children's Health, Kings College London, UK \&

84 MRC Unit The Gambia at London School of Hygiene and Tropical Medicine, United Kingdom

85 31. Mzwakhe Emanuel Nyathi, Department of Animal Services, School of Agriculture, University of 86 Venda, South Africa 
medRxiv preprint doi: https://doi.org/10.1101/2020.06.09.20126979; this version posted June 11, 2020. The copyright holder for this preprint (which was not certified by peer review) is the author/funder, who has granted medRxiv a license to display the preprint in perpetuity.

It is made available under a CC-BY 4.0 International license.

87 32. Maribel Paredes Olortegui, AB PRISMA, Peru

88 33. William A. Petri, University of Virginia, USA

89 34. Prasanna Samuel Premkumar, Christian Medical College, India

90 35. Andrew M. Prentice, MRC Unit The Gambia at London School of Hygiene and Tropical Medicine,

91 United Kingdom

92 36. Najeeb Rahman, Aga Khan University, Pakistan

93 37. Kamran Sadiq, Aga Khan University, Pakistan

94 38. Rajiv Sarkar, Christian Medical College, Vellore, Tamil Nadu, India

95 39. Naomi M. Saville, Institute for Global Health University of College London, United Kingdom

96 40. Bhim P. Shrestha, Health Research and Development Forum (HRDF), Kathmandu, Nepal

97 41. Sanjaya Kumar Shrestha, Walter Reed/AFRIMS Research Unit, University of Bergen Soares,

98 Federal University of Ceará, Brazil

99 42. Bakary Sonko, MRC Unit The Gambia at London School of Hygiene and Tropical Medicine, United 100 Kingdom

101 43. Erling Svensen, Haukeland University Hospital, Norway

102 44. Sana Syed, Department of Pediatrics, Division of Gastroenterology, Hepatology \& Nutrition

103 University of Virginia School of Medicine, USA, and Aga Khan University, Pakistan

104 45. Fayaz Umrani, Aga Khan University, Pakistan

105 46. Honorine D. Ward, Tufts Medical Center, Tufts University School of Medicine, USA

106 47. Pablo Penataro Yori, University of Virginia, USA

107

108

109

110

111

112

113

114

115

116

117

118

119

120

121

122

123

124 
medRxiv preprint doi: https://doi.org/10.1101/2020.06.09.20126979; this version posted June 11, 2020. The copyright holder for this preprint (which was not certified by peer review) is the author/funder, who has granted medRxiv a license to display the preprint in perpetuity.

It is made available under a CC-BY 4.0 International license .

\section{Introduction}

Undernutrition contributes to $45 \%$ of deaths in children under 5 years of age. ${ }^{1,2}$ Wasting, or dangerously low weight for a given length, is a form of undernutrition that results from a loss of muscle and fat tissue from acute malnutrition or infection. ${ }^{3-5}$ An estimated 52 million children worldwide $(7.7 \%$ of children under 5 years) are wasted, with over half living in South Asia; and prevalence has not decreased in 30 years. ${ }^{1,6}$ Wasting in early childhood, defined as a weight-for-length Z-score (WLZ) $<-2$, is a serious condition, as children with less tissue mass have weakened immune systems and are vulnerable to disease, leading to an increased mortality risk, especially if the wasting is severe (WLZ <3)..$^{2-4,7,8}$ Severe wasting can be successfully treated using nutrition rehabilitation with ready-to-usetherapeutic foods and appropriate antimicrobial agents, ${ }^{9,10}$ but relapse and mortality continue to be high. Also, randomized trials have shown inconsistent and small effects of nutritional interventions in preventing moderate wasting. ${ }^{11}$ Although reducing mortality from wasting through treatment is impactful and cost effective, ${ }^{9,12}$ prevention is important as children who recover from wasting have a higher risk of poor long-term growth and neurocognitive development. ${ }^{2,13,14}$ Wasting may also be a risk factor for stunting. ${ }^{8,15,16}$ Research and programs often consider wasting and stunting separately, but similar risk factors underlie each condition, ${ }^{17,1819}$ wasting may reduce linear growth, ${ }^{20}$ and concurrent wasting and stunting heightens mortality risk far beyond the mortality risk of either condition in isolation. ${ }^{3,7,8,21}$ The failure to implement large scale programs to prevent wasting may reflect a historic focus of programs and research on the treatment of severe wasting rather than prevention, or an incomplete understanding of the optimal time to intervene.

Wasting is thought to occur primarily during the critical period for adequate, appropriate and

\section{Pooled longitudinal analyses} safe complementary feeding from ages 6-24 months. ${ }^{22,23}$ Episodes of illness including diarrhea and pneumonia may be followed by wasting or periods of food insecurity could cause more wasting, although a better understanding of the pathways to wasting and therefore the optimal ages/times at which to intervene is needed..$^{24} \mathrm{~A}$ more complete understanding of the epidemiology of wasting and how it varies by age is key to develop and target preventive interventions. ${ }^{11,25,26-28}$

Unlike the cumulative process of linear growth failure leading to stunting, ${ }^{29}$ wasting varies considerably over time both within-individuals and within-populations. ${ }^{16,30}$ This dynamic nature means that the number of wasting episodes within a year is poorly captured in cross-sectional, survey-based estimates of wasting: as many as 13 times the number of children who are wasted at one point in time (prevalence) may experience a period of being wasted within a year (incidence). ${ }^{31}$ Wasting varies within populations in relation to seasonal changes in food insecurity or disease, ${ }^{25,32-34}$ but not consistently between countries; the wasting peaks were not always in the hungry season ${ }^{24}$ and there may be an interaction between season and child age. ${ }^{35}$ The highly seasonal nature of wasting means surveys of prevalence taken at different times have limited comparability. Longitudinal analyses could provide new, crucial information about the optimal timing of intervention delivery to prevent seasonal peaks. ${ }^{24}$ Overall, there is limited research about incident episodes of wasting. ${ }^{1,2}$ Anthropometry measurements from 18 longitudinal cohorts in low- and middle-income countries (LMICs) provided a unique opportunity to examine the life-course of early childhood wasting across diverse populations.

Here, we report a pooled analysis of 18 longitudinal cohorts from 10 LMICs in South Asia, SubSaharan Africa, and Latin America, that measured length and weight monthly among children 0-24 months of age. Our primary objectives were to produce the first large-scale estimates of wasting incidence and recovery and to quantify the temporal and regional variation. We also assessed the concurrence of wasting and stunting and compared estimates of wasting prevalence and incidence. We 
medRxiv preprint doi: https://doi.org/10.1101/2020.06.09.20126979; this version posted June 11, 2020. The copyright holder for this preprint (which was not certified by peer review) is the author/funder, who has granted medRxiv a license to display the preprint in perpetuity.

It is made available under a CC-BY 4.0 International license .

172

173

174

175

176

177

178

179

180

181

182

183

184

185

186

187

188

189

190

191

192

193

194

195

196

197

198

199

200

201

202

203

204

205

206

207

208

209

210

211

212

213

214

215

216

217 hypothesized that a careful examination of wasting incidence and recovery would provide new insights into the timing and burden of wasting and that incidence-based summaries of wasting could differ from summaries based on prevalence.

To test these hypotheses, we analyzed data from the Bill \& Melinda Gates Foundation's Knowledge Integration ( $k i)$ database, which includes observations on millions of participants from varied studies on child growth and development. ${ }^{36}$ We selected longitudinal cohorts for analysis that met 5 criteria: 1) conducted in low- or middle-income countries; 2 ) enrolled children between birth and age 24 months and measured their length and weight repeatedly over time; 3 ) did not restrict enrollment to acutely ill children; 4) enrolled at least 200 children; 5) collected anthropometry measurements at least monthly (Extended Data Fig 1).

Inclusion criteria were defined to select cohorts representative of general populations in low- and middle-income countries (LMICs) with sufficiently frequent measurements to investigate the acute, dynamic nature of wasting. Eighteen cohorts met the inclusion criteria, encompassing 10,854 children and 187,215 total anthropometry measurements from birth to age 24 months (Fig 1).

We calculated weight-for-length Z-scores (WLZ) using WHO 2006 growth standards. ${ }^{37}$ We dropped 381 unrealistic measurements $(0.2 \%)$ of WLZ ( $>5$ or $<-5$ Z-score), following the WHO recommendations. ${ }^{38}$ Cohorts ranged in size from 215 children in the CONTENT cohort ${ }^{39}$ to 2,920 children from the MRC Keneba cohort ${ }^{40}$ (Fig 1). Unless otherwise indicated, we calculated estimates within cohorts and then pooled estimates across cohorts using random effects models fit with restricted maximum likelihood estimation, which is more conservative than fixed-effects models when cohortspecific estimates are heterogeneous. ${ }^{41,42}$ Cohorts were distributed throughout South Asia, Africa, and Latin America, but did not cover entire regions (Extended Data Fig 2). We assessed ki cohort representativeness by comparing Z-score measurements to population-based samples measured in Demographic and Health Surveys (DHS). We found that in Latin America, both weight and length were higher in ki cohorts than in population-based DHS samples, but WLZ distributions were similar (Extended Data Fig 3). WAZ distributions were nearly identical between the Asian and African ki cohorts and population-based DHS samples, but the mean LAZ was lower in ki cohorts than in their target populations, and thus mean WLZ was higher (Extended Data Fig 3). LAZ decreased from birth to 6 months in ki cohorts but held steady over this age range in the DHS data, so the ki cohort estimates of early WLZ recovery may be higher than estimates from population-based samples.

\section{Regional differences in wasting}

Across all observations, mean WLZ was near zero at birth and then increased over the first 6 months before decreasing until 12 months (Fig 2a). Region-specific patterns in Latin America and South Asia reflected the overall pattern, although children in South Asian cohorts had much lower WLZ throughout the age range. Mean WLZ among children from African cohorts was similar to children from Latin American cohorts at birth but then steadily decreased until 12 months (Fig 2a).

Children were wasted for 15,543 (8.7\%) measurements, and severely wasted for 3,290 (1.8\%) measurements. The highest wasting prevalence was at birth, which may result from intrauterine growth restriction or preterm birth, with a random-effects pooled prevalence of $11.9 \%$ (95\% Cl: $7.0,19.5)$, in contrast to prior research findings that show peaks in wasting prevalence occurring in children between 6-24 months old (Fig 2b). ${ }^{35,43-45}$ Across all three regions, there was a consistent pattern in prevalence decreasing from birth to three months and then increasing until children were 12 months old, but in South Asia and Latin America wasting prevalence was higher at birth than at 12 months. Severe wasting followed a similar pattern but was much rarer (Extended data fig 4). Wasting onset was highest during the first 3 months (Fig 2c). Overall, almost half (47.8\%) of children who ever experienced wasting in the 
medRxiv preprint doi: https://doi.org/10.1101/2020.06.09.20126979; this version posted June 11, 2020. The copyright holder for this preprint (which was not certified by peer review) is the author/funder, who has granted medRxiv a license to display the preprint in perpetuity.

It is made available under a CC-BY 4.0 International license .

first two years of life experienced the first onset of wasting in their first 3 months, and an estimated $14.8 \%$ (95\% Cl: 9.1, 23.0) of all children experienced wasting by age 3 months. Prevalence measures of wasting masked how common it was for children to experience wasting in their first 24 months. After birth, a maximum of $7.0 \%(95 \% \mathrm{Cl}: 4.4,11.0)$ of children were wasted any specific age, but $33.3 \%$ (95\% $\mathrm{CI}: 21.1,48.3)$ of children experienced at least one wasting episode by age 24 months, and in South Asian cohorts the proportion was 50.5\% (95\% Cl:41.6, 59.3, Fig 2b, c).

Cohorts from South Asia, where low birthweight is common, ${ }^{46}$ wasting prevalence at birth was $18.9 \%$ (95\% Cl: 15.0, 23.7), suggesting that poor maternal nutrition or maternal illness are key regional drivers of wasting. ${ }^{47}$ There may be regional differences in wasting etiology, as prior research has found that severely wasted children respond slower to treatment in India than in Africa, potentially due to the younger ages of wasted children, more severe wasting episodes, or the use of WLZ to identify severe wasting. ${ }^{17,48-51}$ WLZ cutoffs may capture different severities of growth failure across different populations due to population differences in body composition; children with thinner abdomens will have lower WLZ scores even with identical body fat and muscle composition as children with a thicker abdomens. ${ }^{52,53}$

\section{Seasonality of wasting}

We joined monthly rainfall totals to cohorts by location and year, and for each cohort we estimated a seasonality index based on rainfall (details in Methods)..$^{54,55}$ We estimated monthly average WLZ and examined seasonal changes with respect to rainfall, under the hypothesis that seasonal changes in food availability tied to rainfall and harvests could cause seasonal wasting. Mean WLZ varied dramatically by calendar date in almost all cohorts, with a consistent minimum mean WLZ coinciding with peak rainfall (Fig 3a). Mean WLZ was $-0.23(95 \% \mathrm{Cl}:-0.31,-0.15)$ lower during the three months period of peak rainfall, compared to the mean WLZ in the opposite three-month period of the year, when pooled across cohorts (Fig. 3b). Average seasonal decline in WLZ was -0.26 (95\% Cl: $-0.34,-0.19)$ in cohorts with a seasonality index $>0.8$, but some cohorts evidenced seasonal WLZ declines of more than 0.5 Z. (Fig. 3b).

South Asian cohorts had temporally synchronous rainfall, so we estimated WLZ at birth by calendar month, pooled across the 10 South Asian cohorts. Mean WLZ at birth varied by almost a full standard deviation depending on the month the child was born (range: $-0.5 \mathrm{Z}$ to $-1.3 \mathrm{Z}$; Fig 3c), which suggests that seasonally-influenced maternal nutrition, likely mediated through intrauterine growth restriction or preterm birth, ${ }^{56}$ was a major determinant of child WLZ at birth. Birth month also influenced the effect of season on WLZ trajectories that persisted through a child's second year of life (Extended Data Fig 5).

\section{Wasting incidence and recovery}

There was high variability in wasting status across longitudinal measurements and frequent fluctuations of many children's WLZ measurements around the $-2 \mathrm{Z}$ threshold. We thus defined unique wasting episodes by imposing a 60-day recovery period when a child's WLZ measurements needed to remain above -2 to be considered recovered and at risk for a future episode (Fig 4a). Children who were born wasted were considered to have an incident episode of wasting at birth. Incidence at all ages was higher in South Asia, with highest incidence in the first 3 months, even when excluding episodes of wasting at birth (Fig 4b).

Ultimately, most children recovered from moderate or severe wasting episodes, reinforcing its status as an acute condition. Children met our definition of "recovered" in $91.5 \%$ of episodes of moderate and $82.5 \%$ of episodes of severe wasting. Pooling across cohorts, children recovered from 
medRxiv preprint doi: https://doi.org/10.1101/2020.06.09.20126979; this version posted June 11, 2020. The copyright holder for this preprint (which was not certified by peer review) is the author/funder, who has granted medRxiv a license to display the preprint in perpetuity.

It is made available under a CC-BY 4.0 International license .

$39.2 \%(95 \% \mathrm{Cl}: 33.9,44.7)$ of wasting episodes within 30 days, $64.6 \%(95 \% \mathrm{Cl}: 58.8,70.0))$ within 60 days, and $71.0 \%$ (95\% Cl: $65.5,76.0)$ within 90 days. Median episode length was 42 (95\% Cl: 39, 44) days. We examined the distribution of WLZ in the three-month period after a child was considered recovered from wasting, stratified by the age at which the episode occurred. We found that children recovered to a higher WLZ from at-birth wasting or wasting episodes in the 0-6 month age window compared with episodes that occurred at older ages (Fig 4c). Consistent with larger WLZ increases during recovery from wasting at younger ages, a larger proportion of children recovered within 30,60, and 90 days if the wasting episode occurred before age 6 months (Fig 4d). South Asian cohorts had lower rates of recovery in the 6-18 month age period compared with other regions (Fig 4d). On average, however, the WLZ of children born wasted did not catch up to the WLZ of children not born wasted, and children who were born wasted but recovered had a higher cumulative incidence of wasting after 6 months of age (37.1\% cumulative incidence in children born wasted $[95 \% \mathrm{Cl}: 28.3,47.0]$ vs. $24.3 \%$ cumulative incidence in children not born wasted [95\% Cl: 17.6, 32.5], Fig 4e-f).

\section{Persistent and concurrent growth failure}

The longitudinal cohorts enabled us to identify a subset of children who experienced persistent wasting during their first 24 months. We used a pragmatic definition ${ }^{15}$ that classified children as persistently wasted if $\geq 50 \%$ of their WLZ measurements from birth to 24 months fell below -2 , which could result from many short wasting episodes or a few longer episodes. Among 9,788 children with at least four measurements, $3.7 \%(95 \% \mathrm{Cl}: 2.2,6.1)$ were persistently wasted. Persistent wasting was highest in South Asia, with 6.9\% (95\% Cl: 4.7, 10.2) persistently wasted over the first 24 months of life (Extended Data Fig 4). Among children wasted at birth, $11.4 \%$ of children were persistently wasted after 6 months ( $95 \% \mathrm{Cl}: 9.2,14.0)$ while $6.5 \%$ of children not enrolled wasted were persistently wasted after 6 months (95\% Cl: 4.4, 9.4). A companion article reports key determinants of persistent wasting and its consequences for mortality. ${ }^{57}$

Wasted children who are simultaneously stunted (length-for-age $Z<-2$ ) are at substantially higher risk of mortality than all other growth phenotypes. ${ }^{7}$ We characterized the epidemiology of concurrent wasting and stunting across cohorts and by region to understand when concurrent wasting and stunting first manifests and when it is most common among children under 24 months. Overall, 1,508 children (14\%) were both wasted and stunted during at least one measurement, and $233(2 \%)$ were both severely wasted and severely stunted during at least one measurement. Children who were ever wasted in the first 6 months were $1.8(95 \% \mathrm{Cl}: 1.5,2.3)$ times more likely to be both wasted and stunted between ages 18-24 months. Concurrent wasting and stunting was most common in South Asia, with peak prevalence at ages 12-18 months (Fig $5 a$ ), driven primarily by increases in stunting prevalence as children aged. ${ }^{29}$ Among anthropometry measurements of wasted children, a large proportion were also classified as underweight (37.9\%) or stunted and underweight (39.9\%); the highest proportion of only-wasted children occurred at birth (6.2\% of all children, Fig $5 b)$. A companion article reports the relationship between WLZ and risk of subsequent linear growth failure. ${ }^{57}$

\section{Discussion}

There were several limitations to this analysis. Z-score distributions in the cohorts were broadly similar to measurements from nationally representative surveys, but South Asian cohorts had lower LAZ (Extended data Fig 3), which could have led to higher rates of wasting recovery in early life compared with the general population. Children were not measured at the same ages across all cohorts, and not every child was measured from birth to age 24 months, so the population underlying each age-specific estimate varied. We assumed recovery from moderate wasting was spontaneous because we did not 
medRxiv preprint doi: https://doi.org/10.1101/2020.06.09.20126979; this version posted June 11, 2020. The copyright holder for this preprint (which was not certified by peer review) is the author/funder, who has granted medRxiv a license to display the preprint in perpetuity.

It is made available under a CC-BY 4.0 International license .

have consistent data across cohorts on child treatment referral; wasting recovery may thus be higher in these highly monitored cohorts than in the general population due to treatment referrals. We used weight-for-length Z-score to define wasting, as it was measured in all cohorts, but mid-upper arm circumference (MUAC) as an alternative wasting measure has been found in some settings to be a better predictor of subsequent mortality. ${ }^{58-60}$ Case fatality rates for severe wasting are high so if incident wasting and mortality occurred between monthly visits we could have under-estimated incidence rates, and prevalence estimates could be lower from survivorship bias. ${ }^{61,62}$ Additionally, the WHO Child Growth Standards overestimate wasting at birth among children born preterm, but we did not adjust Zscores for gestational age in the primary analyses because only five included cohorts measured gestational age via either recall of last menstrual period or newborn examination. ${ }^{63}$ Adjustment for gestational age among cohorts that measured it reduced at-birth stunting prevalence by one percent and at-birth underweight prevalence by two percent (Extended data Fig 6). Even if preterm birth accounts for some of at-birth wasting, the small birth size - by any cause - documented in this analysis raises concern because of its consequences for child growth failure and mortality during the first 24 months. ${ }^{57}$

Our results provide new insights into the dynamic process of child wasting with important implications for preventive interventions. WLZ varied dramatically by season in most cohorts, and in South Asia at-birth WLZ varied by 0.7 z-scores $(95 \% \mathrm{Cl}: 0.4,1.0)$ depending on birth month with consequences that persisted throughout the first 24 months (Fig 3, Extended Data Figure 5). These results provide strong support for the development of seasonally targeted interventions to prevent wasting in food-insecure populations. The longitudinal analyses show that the wasting burden is likely far larger than can be quantified with prevailing methods based on cross-sectional, prevalence surveys. By age 24 months, $50 \%$ of children in South Asian cohorts experienced at least one wasting episode and $7 \%$ were persistently wasted - new insights only possible from the longitudinal data analyses. Crucially, we found that onset of wasting was highest from birth to age 3 months, and among children who experience any wasting during their first 24 months, $48 \%$ experience their first wasting episode during this early period. Wasting treatment programs have traditionally focused on children from 6-59 months. Our results should motivate preventive and therapeutic programs to consider extending efforts to mothers during pregnancy and early lactation, and to children during the first months of life. If preventive or therapeutic interventions focus on ages earlier than 6 months, then they must integrate carefully with current recommendations for exclusive breastfeeding.

\section{References}

1. WHO Multicentre Growth Reference Study Group. WHO Child Growth Standards: Length/height-for-age, weight-for-age, weight-for-length, weight-for-height and body mass index-for-age: Methods and development. Geneva: World Health Organization, 2006 (312 pages).

2. Black, R. E. et al. Maternal and child undernutrition and overweight in low-income and middle-income countries. Lancet 382, 427-451 (2013).

3. Briend, A., Khara, T. \& Dolan, C. Wasting and stunting--similarities and differences: policy and programmatic implications. Food Nutr. Bull. 36, S15-23 (2015).

4. Chang, C. Y. et al. Children successfully treated for moderate acute malnutrition remain at risk for malnutrition and death in the subsequent year after recovery. J. Nutr. 143, 215-220 (2013).

5. Malnutrition and Infection: Complex Mechanisms and Global Impacts. https://journals.plos.org/plosmedicine/article?id=10.1371/journal.pmed.0040115.

6. Briend, A. \& Prinzo, Z. W. Dietary management of moderate malnutrition: time for a change. Food Nutr. Bull. 30, S265-266 (2009). 
medRxiv preprint doi: https://doi.org/10.1101/2020.06.09.20126979; this version posted June 11, 2020. The copyright holder for this preprint (which was not certified by peer review) is the author/funder, who has granted medRxiv a license to display the preprint in perpetuity.

It is made available under a CC-BY 4.0 International license .

7. McDonald, C. M. et al. The effect of multiple anthropometric deficits on child mortality: meta-analysis of individual data in 10 prospective studies from developing countries. Am. J. Clin. Nutr. 97, 896-901 (2013).

8. Myatt, M. et al. Children who are both wasted and stunted are also underweight and have a high risk of death: a descriptive epidemiology of multiple anthropometric deficits using data from 51 countries. Arch. Public Health 76, (2018).

9. Bhutta, Z. A. et al. Evidence-based interventions for improvement of maternal and child nutrition: what can be done and at what cost? The Lancet 382, 452-477 (2013).

10. World Health Organization \& Nutrition for Health and Development. Guideline. (2013).

11. Bhutta, Z. A. et al. What works? Interventions for maternal and child undernutrition and survival. Lancet 371, 417-440 (2008).

12. Horton, R. Maternal and child undernutrition: an urgent opportunity. The Lancet 371, 179 (2008).

13. Grantham-McGregor, S. et al. Developmental potential in the first 5 years for children in developing countries. The Lancet 369, 60-70 (2007).

14. Martins, V. J. B. et al. Long-Lasting Effects of Undernutrition. Int. J. Environ. Res. Public. Health 8, 1817-1846 (2011).

15. Richard, S. A. et al. Wasting Is Associated with Stunting in Early Childhood123. J. Nutr. 142, 1291-1296 (2012).

16. Stobaugh, H. C. et al. Children with Poor Linear Growth Are at Risk for Repeated Relapse to Wasting after Recovery from Moderate Acute Malnutrition. J. Nutr. 148, 974-979 (2018).

17. Martorell, R. \& Young, M. F. Patterns of Stunting and Wasting: Potential Explanatory Factors. Adv. Nutr. 3, 227-233 (2012).

18. Saaka, M. \& Galaa, S. Z. Relationships between Wasting and Stunting and Their Concurrent Occurrence in Ghanaian Preschool Children. J. Nutr. Metab. 2016, (2016).

19. Hoffman, D., Cacciola, T., Barrios, P. \& Simon, J. Temporal changes and determinants of childhood nutritional status in Kenya and Zambia. J. Health Popul. Nutr. 36, 27 (2017).

20. Isanaka, S., Hitchings, M. D. T., Berthé, F., Briend, A. \& Grais, R. F. Linear growth faltering and the role of weight attainment: Prospective analysis of young children recovering from severe wasting in Niger. Matern. Child. Nutr. 0, e12817.

21. C, A., T, K., C, D., Ja, B. \& Group, W. T. I. Research priorities on the relationship between wasting and stunting. Field Exch. 5328 (2016).

22. Lenters, L., Wazny, K. \& Bhutta, Z. A. Management of Severe and Moderate Acute Malnutrition in Children. in Reproductive, Maternal, Newborn, and Child Health: Disease Control Priorities, Third Edition (Volume 2) (eds. Black, R. E., Laxminarayan, R., Temmerman, M. \& Walker, N.) (The International Bank for Reconstruction and Development / The World Bank, 2016).

23. Das, J. K., Salam, R. A., Imdad, A. \& Bhutta, Z. A. Infant and Young Child Growth. in Reproductive, Maternal, Newborn, and Child Health: Disease Control Priorities, Third Edition (Volume 2) (eds. Black, R. E., Laxminarayan, R., Temmerman, M. \& Walker, N.) (The International Bank for Reconstruction and Development / The World Bank, 2016).

24. Young, H. \& Marshak, A. A discussion paper on the scope of the problem, its drivers, and strategies for moving forward for policy, practice, and research. 55.

25. Nabwera, H. M., Fulford, A. J., Moore, S. E. \& Prentice, A. M. Growth faltering in rural Gambian children after four decades of interventions: a retrospective cohort study. Lancet Glob. Health 5, e208-e216 (2017).

26. Lenters, L. M., Wazny, K., Webb, P., Ahmed, T. \& Bhutta, Z. A. Treatment of severe and moderate acute malnutrition in low- and middle-income settings: a systematic review, meta-analysis and Delphi process. $B M C$ Public Health 13, S23 (2013).

27. Luby, S. P. et al. Effects of water quality, sanitation, handwashing, and nutritional interventions on diarrhoea and child growth in rural Bangladesh: a cluster randomised controlled trial. Lancet Glob. Health 6, e302-e315 (2018). 
medRxiv preprint doi: https://doi.org/10.1101/2020.06.09.20126979; this version posted June 11, 2020. The copyright holder for this preprint (which was not certified by peer review) is the author/funder, who has granted medRxiv a license to display the preprint in perpetuity.

It is made available under a CC-BY 4.0 International license .

28. Null, C. et al. Effects of water quality, sanitation, handwashing, and nutritional interventions on diarrhoea and child growth in rural Kenya: a cluster-randomised controlled trial. Lancet Glob. Health 6, e316-e329 (2018).

29. Benjamin-Chung, J. et. al. (submitted). Early childhood linear growth failure in low-and middle-income countries. (2020).

30. Osgood-Zimmerman, A. et al. Mapping child growth failure in Africa between 2000 and 2015. Nature 555, 4147 (2018).

31. Bulti, A. et al. Improving estimates of the burden of severe acute malnutrition and predictions of caseload for programs treating severe acute malnutrition: experiences from Nigeria. Arch. Public Health 75, (2017).

32. Brown, K. H., Black, R. E. \& Becker, S. Seasonal changes in nutritional status and the prevalence of malnutrition in a longitudinal study of young children in rural Bangladesh. Am. J. Clin. Nutr. 36, 303-313 (1982).

33. Egata, G., Berhane, Y. \& Worku, A. Seasonal variation in the prevalence of acute undernutrition among children under five years of age in east rural Ethiopia: a longitudinal study. BMC Public Health 13, (2013).

34. Kinyoki, D. K. et al. Space-time mapping of wasting among children under the age of five years in Somalia from 2007 to 2010. Spat. Spatio-Temporal Epidemiol. 16, 77-87 (2016).

35. Schoenbuchner, S. M. et al. The relationship between wasting and stunting: a retrospective cohort analysis of longitudinal data in Gambian children from 1976 to 2016. Am. J. Clin. Nutr. doi:10.1093/ajcn/nqy326.

36. Peppard, T. et al. (submitted). Combined longitudinal growth cohorts from infants born in South Asia, SubSaharan Africa and Latin America. (2020).

37. WHO Multicentre Growth Reference Study Group. WHO child growth standards: length/height-for-age, weight-for-age, weight-for-length, weight-for-height and body mass index-for-age: Methods and development. Geneva World Health Organ. 312 pages (2006).

38. Organization, W. H. \& Fund (UNICEF), U. N. C. Recommendations for data collection, analysis and reporting on anthropometric indicators in children under 5 years old. (World Health Organization, 2019).

39. Jaganath, D. et al. First Detected Helicobacter pylori Infection in Infancy Modifies the Association Between Diarrheal Disease and Childhood Growth in Peru. Helicobacter 19, 272-279 (2014).

40. Hennig, B. J. et al. Cohort Profile: The Kiang West Longitudinal Population Study (KWLPS) - a platform for integrated research and health care provision in rural Gambia. Int. J. Epidemiol. 46, e13 (2017).

41. Viechtbauer, W. Bias and Efficiency of Meta-Analytic Variance Estimators in the Random-Effects Model. J. Educ. Behav. Stat. 30, 261-293 (2005).

42. Raudenbush, S. W. Analyzing Effect Sizes: Random-Effects Models. in The Handbook of Research Synthesis and Meta-Analysis 295-315 (Russell Sage Foundation, 2009).

43. de Onis, M. et al. Comparison of the World Health Organization (WHO) Child Growth Standards and the National Center for Health Statistics/WHO international growth reference: implications for child health programmes. Public Health Nutr. 9, 942-947 (2006).

44. Garenne, M., Myatt, M., Khara, T., Dolan, C. \& Briend, A. Concurrent wasting and stunting among under-five children in Niakhar, Senegal. Matern. Child. Nutr. 15, (2019).

45. Payandeh, A., Saki, A., Safarian, M., Tabesh, H. \& Siadat, Z. Prevalence of Malnutrition among Preschool Children in Northeast of Iran, A Result of a Population Based Study. Glob. J. Health Sci. 5, 208-212 (2013).

46. Blencowe, H. et al. National, regional, and worldwide estimates of low birthweight in 2015, with trends from 2000: a systematic analysis. Lancet Glob. Health 0, (2019).

47. Ashorn, P. et al. Co-causation of reduced newborn size by maternal undernutrition, infections, and inflammation. Matern. Child. Nutr. 14, e12585 (2018).

48. Victora, C. G., Onis, M. de, Hallal, P. C., Blössner, M. \& Shrimpton, R. Worldwide Timing of Growth Faltering: Revisiting Implications for Interventions. Pediatrics 125, e473-e480 (2010).

49. Hemalatha, R., Radhakrishna, K. \& Kumar, Bn. Undernutrition in children \& critical windows of opportunity in Indian context. Indian J. Med. Res. 148, 612 (2018). 
medRxiv preprint doi: https://doi.org/10.1101/2020.06.09.20126979; this version posted June 11, 2020. The copyright holder for this preprint (which was not certified by peer review) is the author/funder, who has granted medRxiv a license to display the preprint in perpetuity.

It is made available under a CC-BY 4.0 International license .

50. Global, regional, and national causes of under-5 mortality in 2000-15: an updated systematic analysis with implications for the Sustainable Development Goals - ScienceDirect. https://www.sciencedirect.com/science/article/pii/S0140673616315938.

51. Efficacy of three feeding regimens for home-based management of children with uncomplicated severe acute malnutrition: a randomised trial in India | BMJ Global Health. https://gh.bmj.com/content/1/4/e000144.

52. Victora, C. G. The Association between Wasting and Stunting: An International Perspective. J. Nutr. 122, 11051110 (1992).

53. Post, C. L. \& Victora, C. G. The low prevalence of weight-for-height deficits in Brazilian children is related to body proportions. J. Nutr. 131, 1290-1296 (2001).

54. Harris, I., Jones, P. D., Osborn, T. J. \& Lister, D. H. Updated high-resolution grids of monthly climatic observations - the CRU TS3.10 Dataset. Int. J. Climatol. 34, 623-642 (2014).

55. Walsh, R. P. D. \& Lawler, D. M. Rainfall Seasonality: Description, Spatial Patterns and Change Through Time. Weather 36, 201-208 (1981).

56. Christian, P. et al. Risk of childhood undernutrition related to small-for-gestational age and preterm birth in low- and middle-income countries. Int J Epidemiol 42, 1340-1355 (2013).

57. Mertens, A. et al. (submitted). Causes and consequences of child growth failure in low- and middle-income countries. (2020).

58. Aguayo, V. M., Aneja, S., Badgaiyan, N. \& Singh, K. Mid upper-arm circumference is an effective tool to identify infants and young children with severe acute malnutrition in India. Public Health Nutr. 18, 3244-3248 (2015).

59. Kikafunda, J. K., Walker, A. F., Collett, D. \& Tumwine, J. K. Risk factors for early childhood malnutrition in Uganda. Pediatrics 102, E45 (1998).

60. Berkley, J. et al. Assessment of severe malnutrition among hospitalized children in rural Kenya: comparison of weight for height and mid upper arm circumference. JAMA 294, 591-597 (2005).

61. Manary, M. J. \& Sandige, H. L. Management of acute moderate and severe childhood malnutrition. BMJ 337, a2180 (2008).

62. Collins, S. et al. Management of severe acute malnutrition in children. The Lancet 368, 1992-2000 (2006).

63. Perumal, N. et al. Effect of correcting for gestational age at birth on population prevalence of early childhood undernutrition. Emerg. Themes Epidemiol. 15, 3 (2018). 
medRxiv preprint doi: https://doi.org/10.1101/2020.06.09.20126979; this version posted June 11, 2020. The copyright holder for this preprint (which was not certified by peer review) is the author/funder, who has granted medRxiv a license to display the preprint in perpetuity.
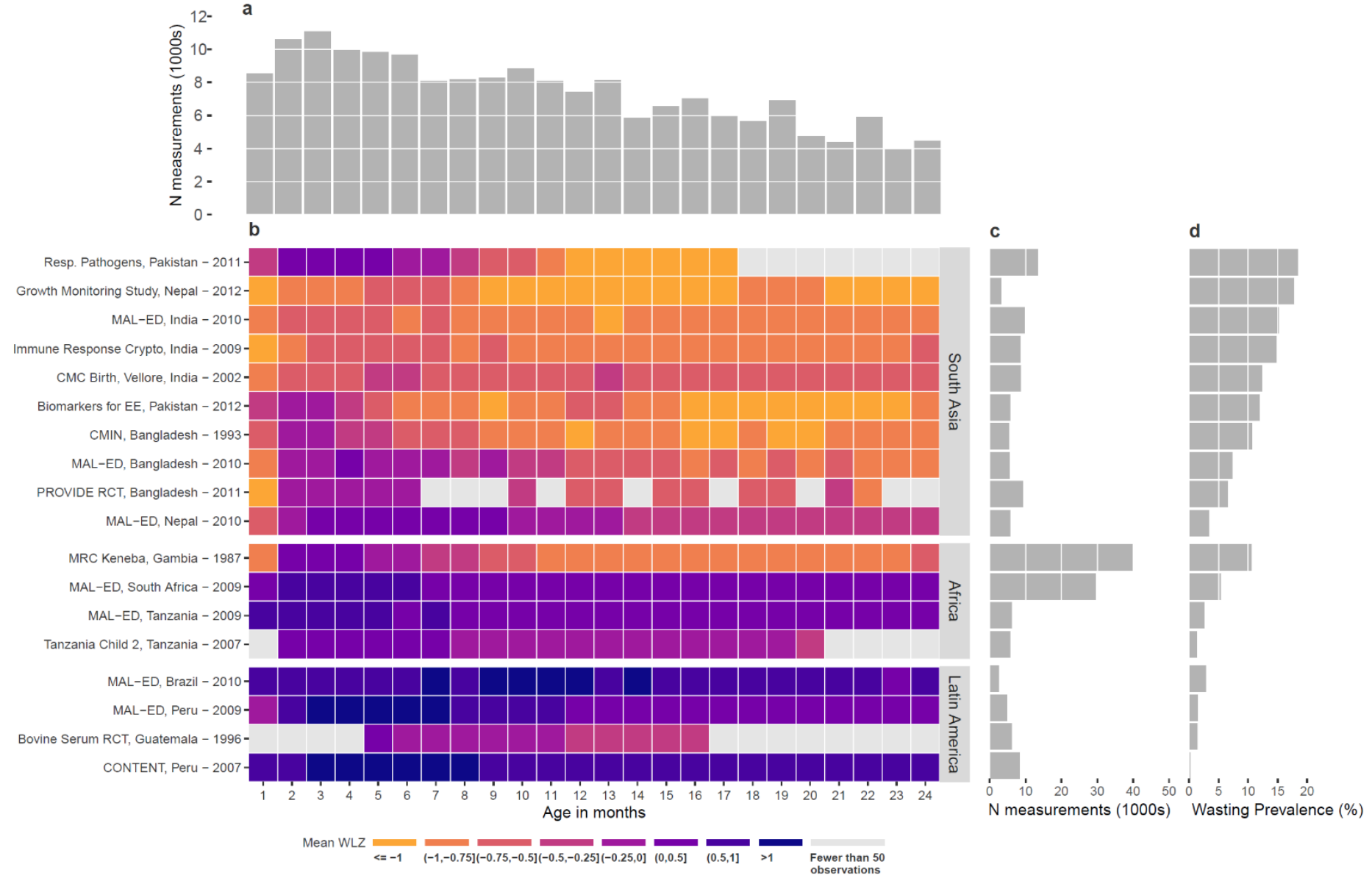

484 Figure 1| Summaries of included cohorts.

485 (a) Number of observations (1000s) across cohorts by age in months. (b) Mean weightfor-length Z-scores (WLZ) by age in months for each included cohort. Cohorts are sorted by geographic region and overall mean weight-for-length Z-score. The country of each cohort and the start year is printed by each cohort name. (c) The number of as proportion of measurements with $\mathrm{WLZ}<-2$. 
medRxiv preprint doi: https://doi.org/10.1101/2020.06.09.20126979; this version posted June 11, 2020. The copyright holder for this preprint (which was not certified by peer review) is the author/funder, who has granted medRxiv a license to display the preprint in perpetuity.

It is made available under a CC-BY 4.0 International license.

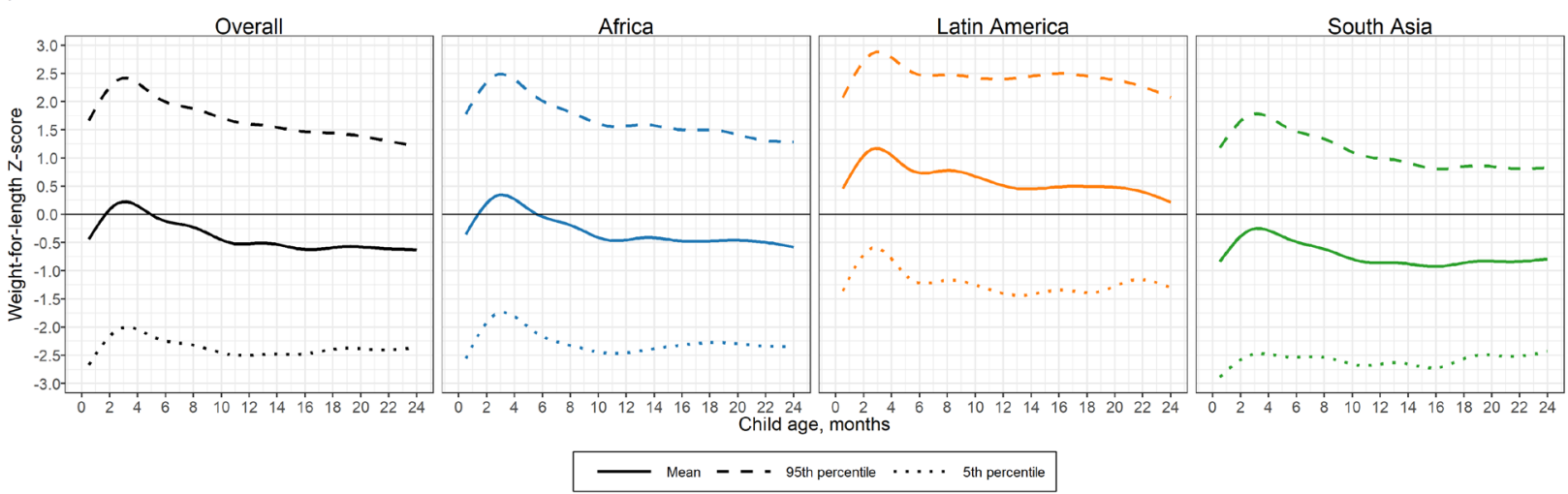

b

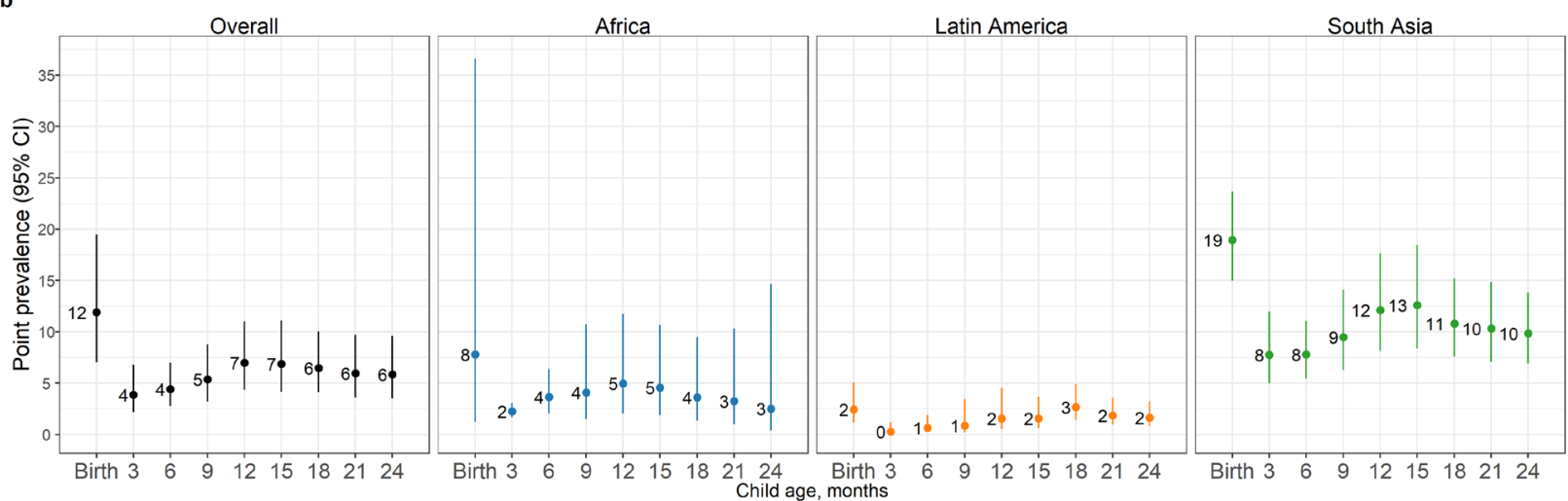

Overall

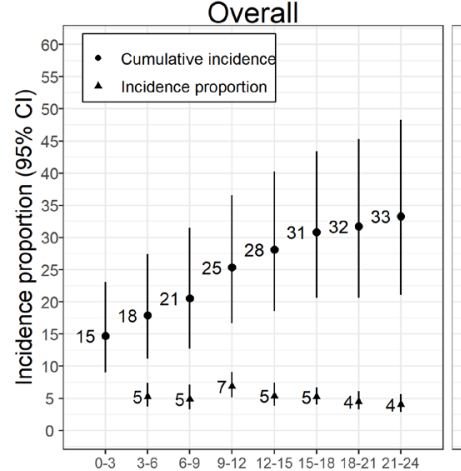

Africa

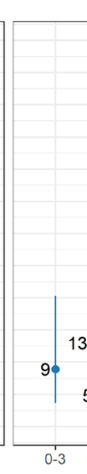
Child age, months

Latin America

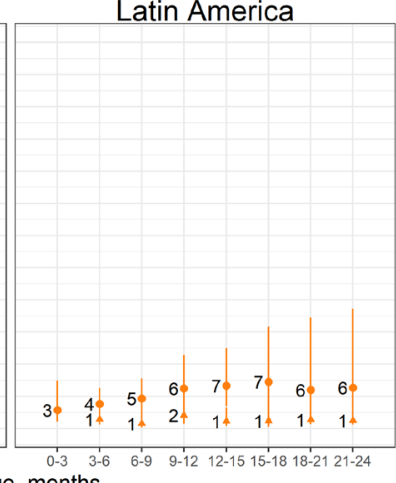

South Asia

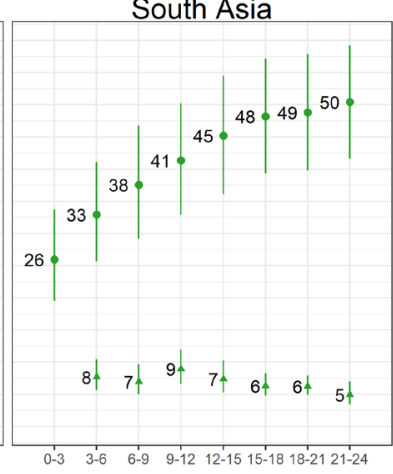

Figure 2 | WLZ, prevalence and incidence of wasting by age and region.

(a) Mean, 5th and 95th percentile of weight-for-length Z-score (WLZ) by age in 18 included longitudinal cohorts, overall ( $\mathrm{N}=18$ studies; $\mathrm{N}=3,858-10,388$ observations per month) and stratified by region (Africa: $\mathrm{N}=4$ studies, $\mathrm{N}=1,067-5,428$ observations; Latin America: $\mathrm{N}=4$ studies, $\mathrm{N}=417-1358$ observations, South Asia 10 studies, $\mathrm{N}=2,223-4,142$ observations).

(b) Age-specific wasting prevalence, defined as WLZ $<-2$, overall ( $N=3,985-9,353$ children) and stratified by region (Africa: 1,701-5,017 children, Latin America: $\mathrm{N}=209-996$ children, South Asia: $\mathrm{N}=1,994-3,605$ children).

(c) Age-specific wasting incidence overall ( $\mathrm{N}=5,848-9,841$ children) and stratified by region (Africa: Cumulative incidence measures the proportion of children who have ever experienced wasting since birth, while the new incident cases represent the proportion of children at risk who had an episode of wasting begin during the age range.

505 Estimation details for all plots are in the methods. 
medRxiv preprint doi: https://doi.org/10.1101/2020.06.09.20126979; this version posted June 11, 2020. The copyright holder for this preprint (which was not certified by peer review) is the author/funder, who has granted medRxiv a license to display the preprint in perpetuity. It is made available under a CC-BY 4.0 International license.
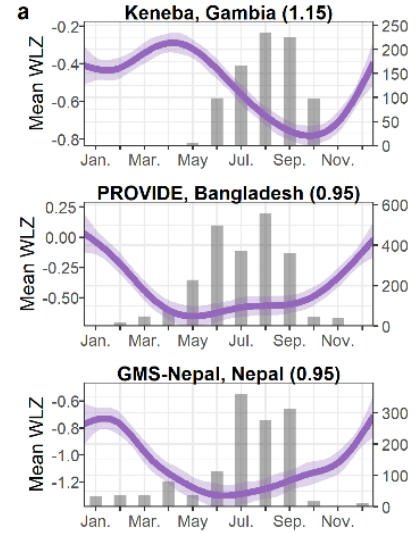

MAL-ED, Nepal (0.89)

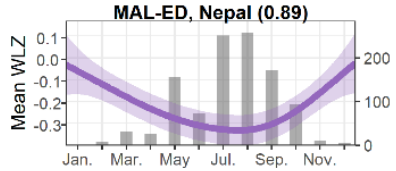

MAL-ED, Bangladesh (0.87)
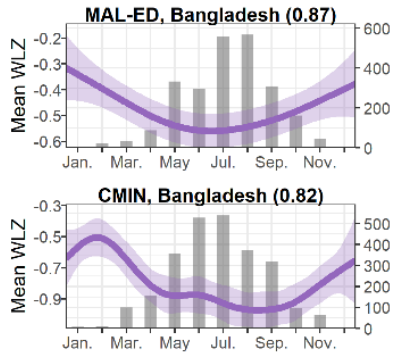

IRC, India (0.82)

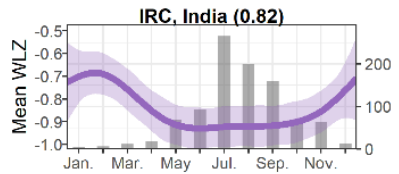

MAL-ED, India (0.82)
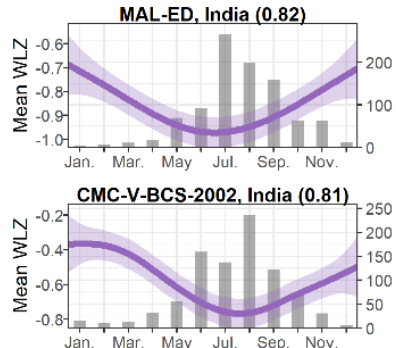
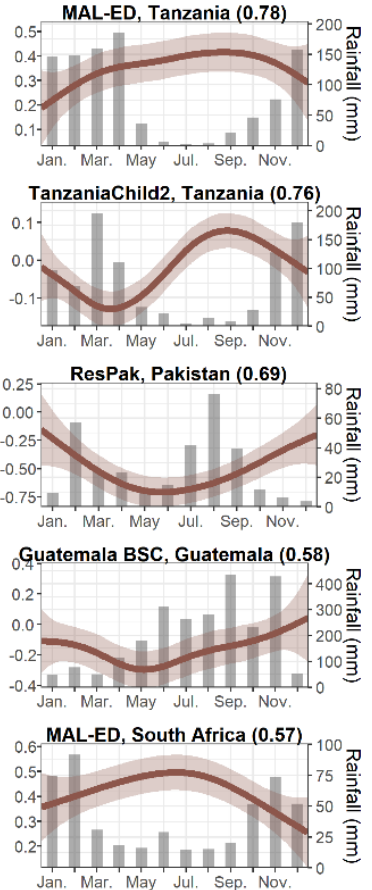

EE, Pakistan (0.54)
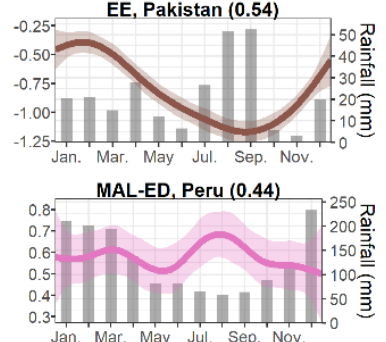

MAL-ED, Brazil (0.4)
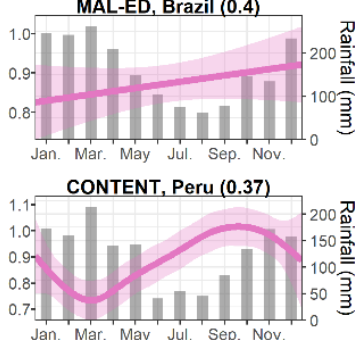
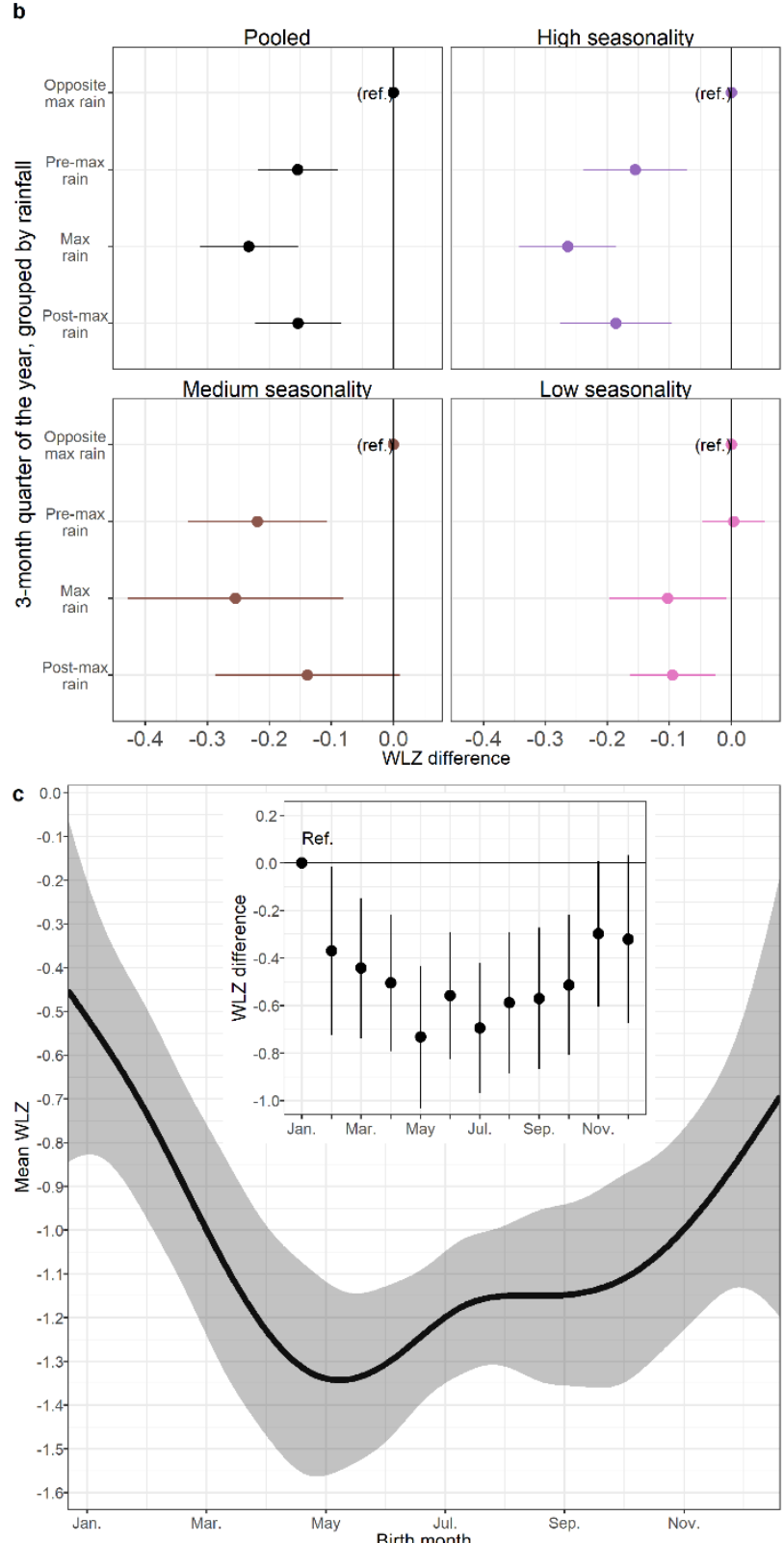

\section{Figure 3 | Mean weight-for-length Z-scores by age and season.}

(a) Cubic splines of mean WLZ over day of the year, superimposed over histograms of monthly mean rainfall over study periods, with the seasonality index printed in parentheses beside the cohort name, and splines colored by high $(\geq 0.8)$, medium ( $<0.8$ and $\geq 0.5$ ), and low seasonality categories $(<0.5)$. Sample sizes range from 215 children (8,339 measurements) in CONTENT to 2,396 (29,596 measurements) in the Tanzania Child cohort.

(b) Mean differences in child WLZ between quarters of the year defined around the 3-month period with the highest mean rainfall, pooled across cohorts in panel (a) overall ( $N=18$ cohorts, 2,545-40,115 observations) and by seasonality index (high: $\mathrm{N}=9$ cohorts, $5,372-40,115$ observations, medium: $\mathrm{N}=6$ cohorts, $2,545-$ 29,518 observations, low: $\mathrm{N}=3$ cohorts, 4,837-8,339 observations).

(c) Cubic spline of mean WLZ at birth across birth months among 2,334 children with WLZ measured at birth in ten South Asian cohorts, with mean differences in WLZ at birth by birth month in the inset plot. 
medRxiv preprint doi: https://doi.org/10.1101/2020.06.09.20126979; this version posted June 11, 2020. The copyright holder for this preprint (which was not certified by peer review) is the author/funder, who has granted medRxiv a license to display the preprint in perpetuity.

It is made available under a CC-BY 4.0 International license .

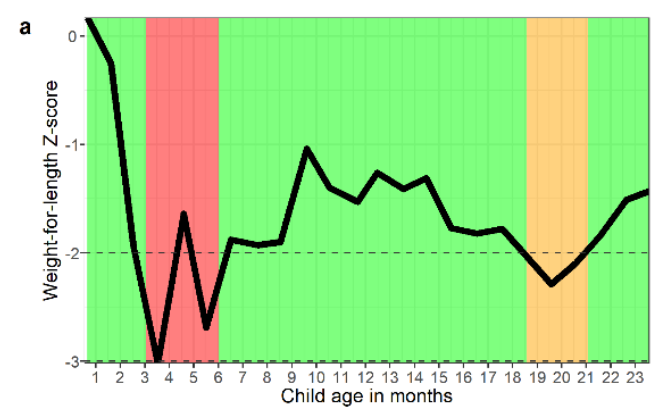

b

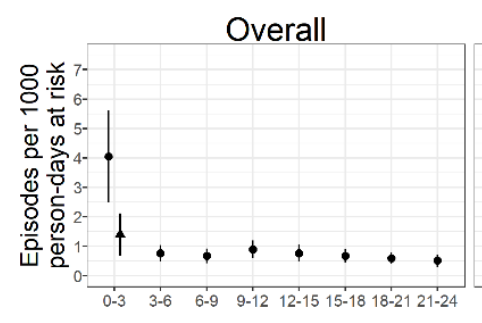

d

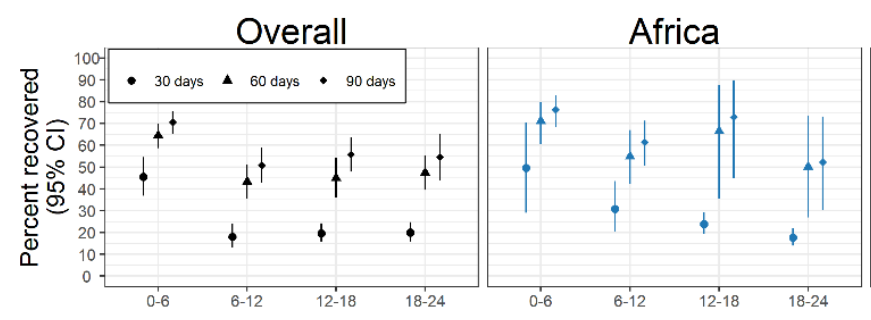

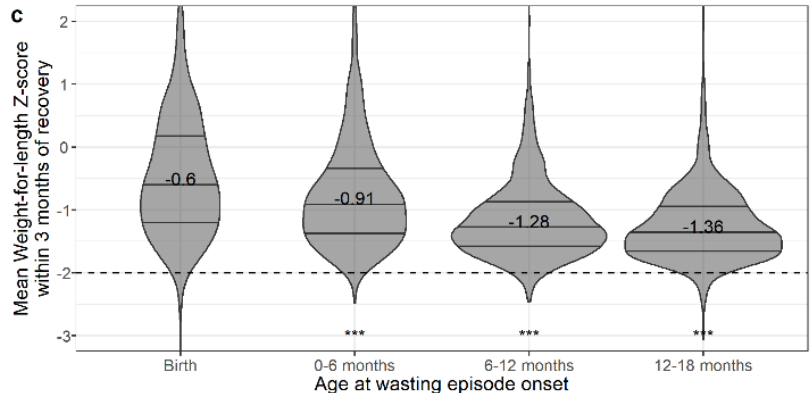

Africa

Latin America

South Asia

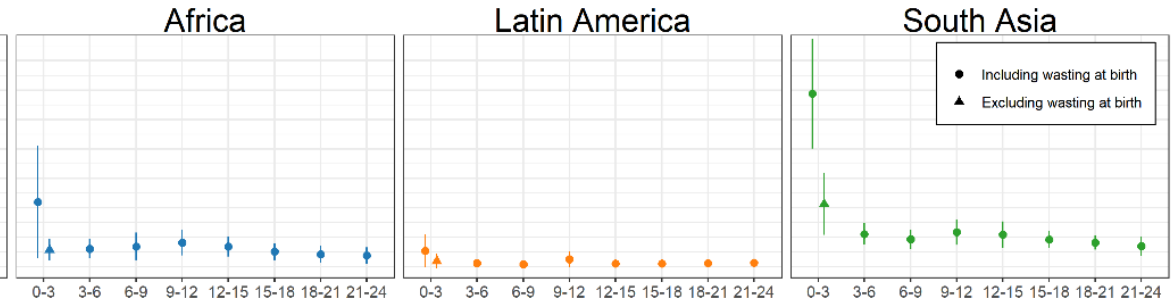

Child age, months

Child age, months

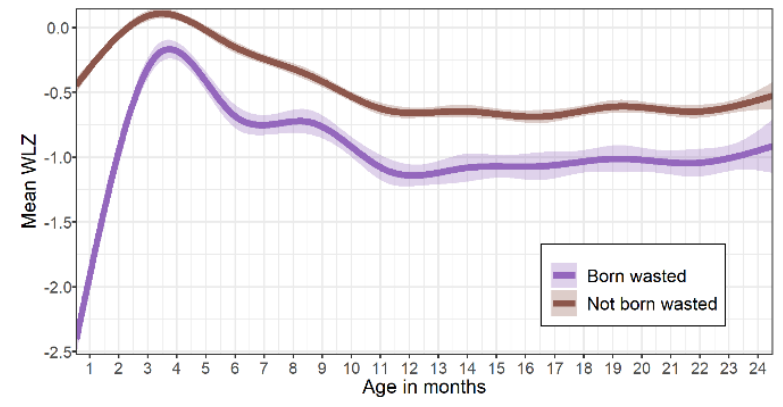

Latin America

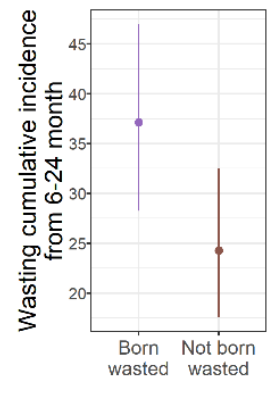

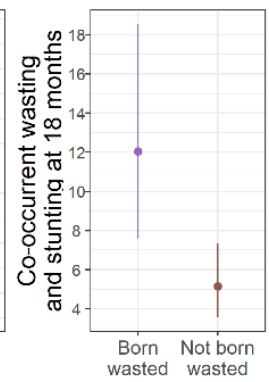

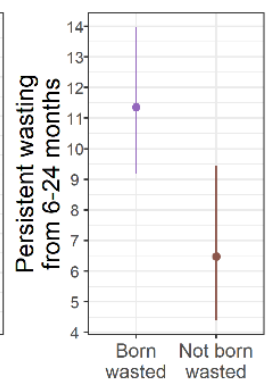

Born Not born

Born Not born

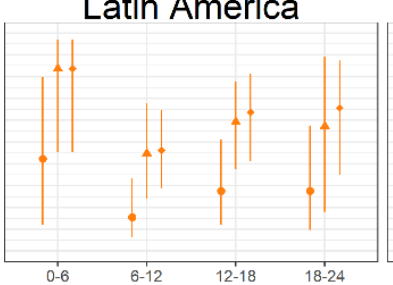

South Asia

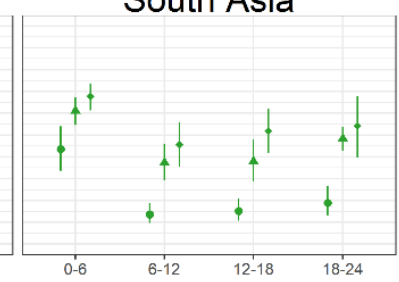


medRxiv preprint doi: https://doi.org/10.1101/2020.06.09.20126979; this version posted June 11, 2020. The copyright holder for this preprint (which was not certified by peer review) is the author/funder, who has granted medRxiv a license to display the preprint in perpetuity.

It is made available under a CC-BY 4.0 International license.

\section{Figure 4| Wasting incidence rate and recovery.}

522 (a) Example child WLZ trajectory and wasting episode classifications.

523 (b) Wasting incidence rate per 1,000 days at risk, stratified by age and region (Overall: $\mathrm{N}=484,737-$

524769,154 child-days per estimate, Africa: $\mathrm{N}=245,046-407,940$ child-days, Latin America: $\mathrm{N}=44,306-$

525101,549 child-days, South Asia: $\mathrm{N}=178,112-302,470$ child-days).

526 (c) The distribution of children's mean WLZ in the three months following recovery from wasting, with

527 inter-quartile range marked. Children wasted before age 6 months experienced larger improvements in

528 WLZ compared with children wasted at older ages $(p<0.001)$. The analysis uses 3,563 observations of

5292,205 children who recovered from wasting episodes, with 1,219 observations at birth, 614 observations

530 from 0-6 months, 794 observations from 6-12 months, and 936 observations from 12-18 months.

531 (d) Recovery proportion from wasting within 30,60 , and 90 days of episode onset ( $N=18$ cohorts, 5,373 532 wasting episodes).

533 (e) Mean WLZ by age shows that children born wasted ( $N=758$ children, 13,958 observations) did not

534 catch up to children not born wasted ( $N=3,306$ children, 61,618 observations).

535 (f) Higher measures of wasting after 6 months of age among children born wasted $(\mathrm{N}=758)$ compared to 536 those who were not $(\mathrm{N}=3,306)$.

537 Estimation details for all plots are in the methods.

538

539 
medRxiv preprint doi: https://doi.org/10.1101/2020.06.09.20126979; this version posted June 11, 2020. The copyright holder for this preprint (which was not certified by peer review) is the author/funder, who has granted medRxiv a license to display the preprint in perpetuity.

It is made available under a CC-BY 4.0 International license.
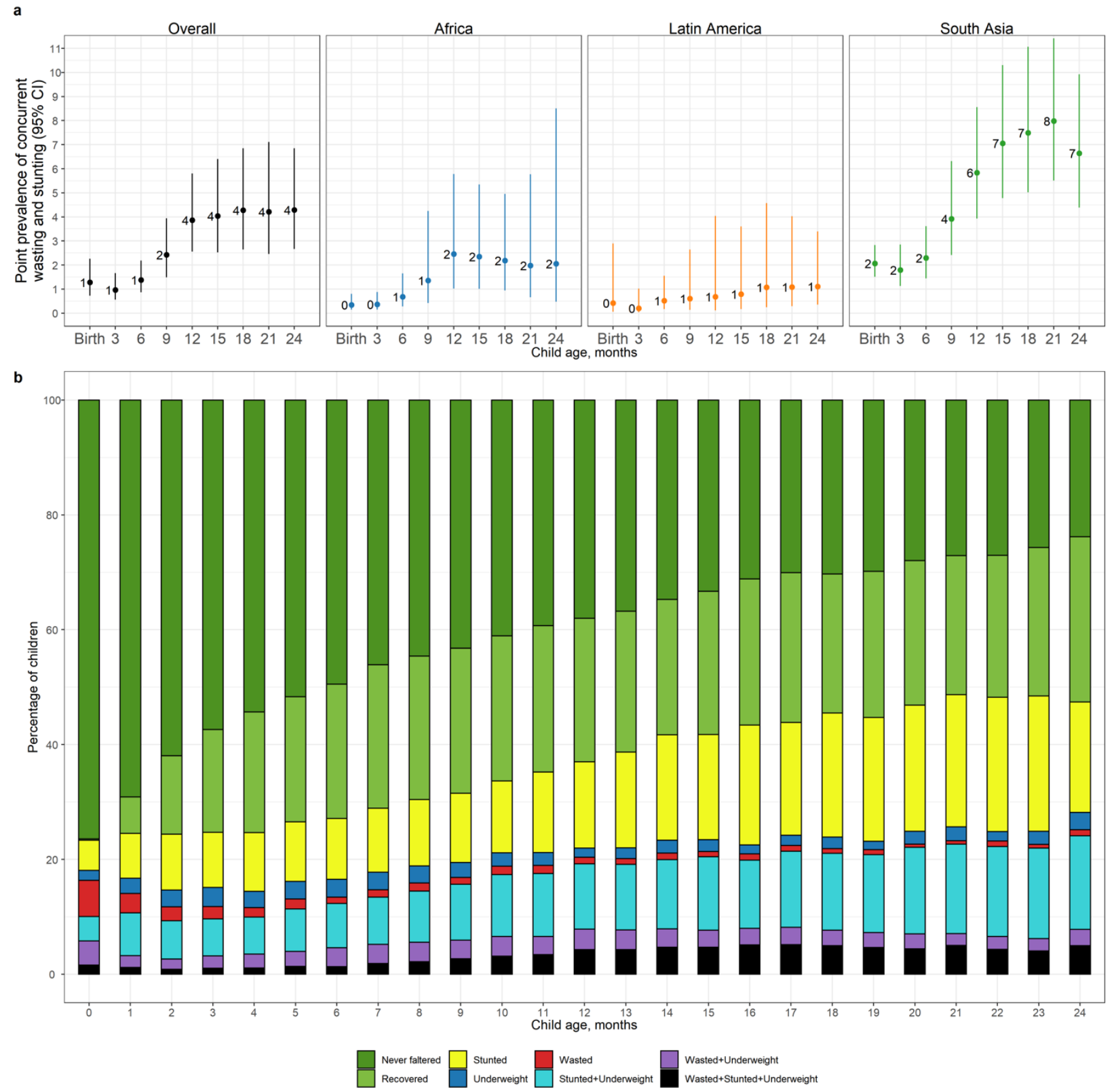
Figure 5| Co-occurrence of wasting, stunting, and underweight.

(a) Age-specific prevalence of co-occurrent wasting and stunting overall ( $N=3,984$ to 9,346 children) and stratified by region (Africa: $\mathrm{N}=1,700-5,014$ children, Latin America: $\mathrm{N}=290-996$ children, South Asia: $\mathrm{N}=1,994-3,601$ children).

(b) Proportion of children with measures of growth failure, alone or combined. Children never faltered at an age in months had never been wasted, stunted, or underweight, and children in the "recovered" category were not wasted, stunted, or underweight but had experienced at least one of these conditions previously. All children who were wasted and stunted were also underweight. The number of children contributing to each age ranges from 2,077 to 8,652

550 children, with 10,815total children.

551 Estimation details for all plots are in the methods. 
medRxiv preprint doi: https://doi.org/10.1101/2020.06.09.20126979; this version posted June 11, 2020. The copyright holder for this preprint (which was not certified by peer review) is the author/funder, who has granted medRxiv a license to display the preprint in perpetuity.

It is made available under a CC-BY 4.0 International license .

\section{Materials and Methods}

\section{Study designs and inclusion criteria}

555 We included all longitudinal observational studies and randomized trials available through the $k i$ project on April 2018 that met five inclusion criteria (Extended Data Figure 1): 1) conducted in low- or middleincome countries; 2 ) enrolled children between birth and age 24 months and measured their length and weight repeatedly over time; 3 ) did not restrict enrollment to acutely ill children; 4) enrolled at least 200 children; 5) collected anthropometry measurements at least monthly. The frequency of measurements was assessed by calculating the median days between measurements. Our pre-specified analysis protocol stipulated that if randomized trials found effects of interventions on growth, the analysis would only include the control arm only; yet, all intervention trials that met the inclusion criteria had null effects on growth, so all arms were included. We included all children under 24 months of age, assuming months were 30.4167 days. We excluded extreme measurements of WLZ $>5$ or $<-5$ and of WAZ $<-6$ or $>5$, consistent with 2006 WHO Growth Standards recommendations. ${ }^{1}$ We checked for cohort-wide anthropometry measurement quality by plotting Z-score densities and calculating the proportion of length measurements where length decreased beyond the expected technical error of measurement compared to the last measurement on a child. One cohort, MAL-ED Pakistan, was excluded because measurements exhibited a multimodal WLZ distribution with scores binned at $-2,-1.5$, and -1 instead of continuously distributed.

\section{Outcome definitions}

We used the following outcome measures in the analysis:

Weight-for-Length Z-scores were calculated using the 2006 WHO growth standards, ${ }^{2}$ and mean WLZ was calculated within strata of interest. We used the medians of triplicate measurements of lengths and weights of children from pre-2006 cohorts to re-calculate $Z$ scores to the 2006 standard. Prevalent wasting was defined as the proportion of measurements within a specific stratum (e.g., age) below the 2006 WHO standard -2 WLZ, and analogously below the 2006 WHO standard - 3 WLZ for severe wasting. For each age, we included children with WLZ measurements within one month before and after that age in the point prevalence estimate (e.g., for point prevalence at 6 months, we include children aged 5-7 months).

Incident wasting episodes were defined as a change in WLZ from above $-2 \mathrm{Z}$ in the prior measurement to below $-2 \mathrm{Z}$ in the current measurement. Similarly, we defined severe wasting episodes using $-3 \mathrm{Z}$ cutoff. We assumed a 60-day washout period between episodes of wasting before a new episode of wasting could occur (Fig 4a). Children were considered at risk for wasting at birth, so children born wasted were considered to have an incident episode of wasting at birth. Children were also assumed to be at risk of wasting at the first measurement in studies that enrolled children after birth, so children wasted at the first measurement in a non-birth cohort were assumed to have incident wasting occurring at the age halfway between birth and the first measurement. proportion of children at risk who became wasted during the age period (the onset of new episodes). currently wasted or severely wasted. We required a child to maintain WLZ above -2 for 60 days to be considered "recovered". Children were only considered "at risk" for recovery if their prior measurement was below -2 WLZ. We measured the proportion of children who recover from moderate wasting (WLZ <-2) within 30,60, and 90 days of the onset of the episode. We assumed recovery from 
medRxiv preprint doi: https://doi.org/10.1101/2020.06.09.20126979; this version posted June 11, 2020. The copyright holder for this preprint (which was not certified by peer review) is the author/funder, who has granted medRxiv a license to display the preprint in perpetuity.

It is made available under a CC-BY 4.0 International license .

wasting was spontaneous because we did not have consistent information on referral guidelines across cohorts in the analysis, but some children with moderate wasting may have been referred to clinical facilities for outpatient treatment.

Wasting duration was estimated by counting the days between the onset of wasting and recovery within an individual child. We assumed that the episode started or ended at the midpoint between measurements. For example, if a child was not wasted at age 40 days, wasted at age 70 days, and not wasted at age 100 days, the duration of the wasting episode was: $(70-40) / 2+(100-70) / 2=30$ days. We calculated the median duration of wasting episodes among cohorts where children recovered during the study period from $>50 \%$ of observed wasting episodes, as the duration of episodes that extended beyond study period is unknown. Therefore, the median duration could only be calculated when less than half of episodes were censored. Confidence intervals were calculated using the quantile method. Incidence rate of wasting was calculated during defined age ranges as the number of incident episodes of wasting per 1,000 child-days at risk during the age range. Children were considered "at risk" for incident wasting episodes if they were not currently wasted and were classified as recovered from any prior wasting episode (beyond the 60-day washout period). Therefore, wasted children, or children within the washout period, did not contribute to the person-time at risk for wasting used to calculate wasting incidence. To calculate person-time at risk of wasting, we assumed that the onset of a wasting episode occurred when the child's age was at the midpoint between the measurement of WLZ $\geq-2$ and the measurement of $W L Z<-2$, and conversely the time of recovery occurred when the child's age was at the midpoint between the last measurement of $W L Z<-2$ and the first measurement of WLZ $\geq-2$ within the 60-day washout period (Fig 4a).

Persistent wasting was defined as a $>50 \%$ longitudinal prevalence of below -2 WLZ (wasting), and analogously $>50 \%$ longitudinal prevalence of below $-3 \mathrm{WLZ}$ for persistent severe wasting. ${ }^{3}$

Concurrent prevalence of wasting and stunting was defined as the proportion of measurements at a specific age when a child was both wasted and stunted at the same measurement. For each age, we included children with WLZ and LAZ measurements within one month before and after that age in the point prevalence estimate (e.g., for point prevalence at 6 months, we include children aged 5-7 months). Prevalent underweight was defined as the proportion of measurements at a specific age below the 2006 WHO standard -2 WAZ. For each age, we included children with WAZ measurements within one month before and after that age in the point prevalence estimate (e.g., for point prevalence at 6 months, we include children aged 5-7 months).

\section{Subgroups of interest}

We stratified the above outcomes of interest within the following subgroups: Child age, grouped into one, three, or six month intervals, (depending on the outcome); the region of the world (Asia, subSaharan Africa, Latin America); the month of the year, and the combinations of the above categories.

\section{Statistical analysis}

All analyses were conducted in $\mathrm{R}$ version 3.6.2. Supplementary pooled, regional, and cohort-specific results, and sensitivity analyses are available in online supplements at (https://childgrowth.github.io/wasting).

\section{Fixed and random effects models}


medRxiv preprint doi: https://doi.org/10.1101/2020.06.09.20126979; this version posted June 11, 2020. The copyright holder for this preprint (which was not certified by peer review) is the author/funder, who has granted medRxiv a license to display the preprint in perpetuity.

It is made available under a CC-BY 4.0 International license.

We estimated wasting outcomes within specific cohorts and pooled estimates within each age strata using random effects models. We estimated overall pooled effects, and pooled estimates specific to South Asian, African, or Latin American cohorts. We pooled all statistics using random effects models, and repeated the pooling using fixed effects models as a sensitivity analysis. The pooling methods are detailed in Benjamin-Chung (2020). ${ }^{4}$

All pooling was completed using the rma() function from the "metafor" package in the R language (version 3.4.2). ${ }^{5}$

\section{Fitted spline curves}

Fitted smoothers used in manuscript figures were fit using cubic splines and generalized crossvalidation, except in Figure 2a, where locally estimated scatterplot smoothing (LOESS) was applied to monthly mean weight-for-length Z-scores pooled across cohorts using random-effects models. ${ }^{6} \mathrm{We}$ estimated approximate $95 \%$ simultaneous confidence intervals around the cubic splines using a parametric bootstrap that resampled from the posterior the generalized additive model parameter variance-covariance matrix. ${ }^{7}$

\section{Seasonality analysis}

We compared mean WLZ over day of the year, over child birth day, and over seasons defined by rainfall. We estimated mean WLZ by cohort over day of the year and child birth day using cubic splines (Fig. 3a, c). ${ }^{8}$ Splines of WLZ over day of the year were plotted over country-level monthly mean rainfall averaged over the years a study measured child anthropometry below ages 24 months (Fig. 3a). Rainfall data was extracted from the University of East Anglia Climate Research Unit CRU TS dataset (version 3.23, 23 October 2015). ${ }^{9}$

The season of peak rainfall was defined as the three-month period with the highest mean rainfall. Mean differences in WLZ between three-month quarters was estimated using linear regression models. We compared the consecutive three months of the maximum average rainfall over the study period, as well as the three months prior and the three months after the maximum-rainfall period, to a reference level of the three months opposite the calendar year of the maximum-rainfall period. We used all WLZ measurements of children under two years of age.

Estimates were unadjusted for other covariates because we assumed that seasonal effects on WLZ were exogenous and could not be confounded. Mean differences in WLZ were pooled across cohorts using random-effects models, with cohorts grouped by the Walsh and Lawler seasonality index. ${ }^{10}$ Cohorts from years with a seasonal index $\geq 0.8$ were classified as occurring in locations with high seasonality, cohorts with a seasonal index $<0.8$ and $\geq 0.5$ were classified as occurring in locations with medium seasonality, and cohorts with a seasonal index $<0.5$ were classified as occurring in locations with low seasonality, with cutpoints chosen to keep cohorts from the same country grouped together. ${ }^{10}$

$$
\text { Seasonal Index }=\frac{1}{R} \sum_{n=1}^{n=12}\left|X_{n}-\frac{R}{12}\right|
$$

Where $\mathrm{R}=$ total annual precipitation and $X_{n}=$ monthly precipitation. 
medRxiv preprint doi: https://doi.org/10.1101/2020.06.09.20126979; this version posted June 11, 2020. The copyright holder for this preprint (which was not certified by peer review) is the author/funder, who has granted medRxiv a license to display the preprint in perpetuity.

It is made available under a CC-BY 4.0 International license .

Estimation of mean LAZ, WAZ, and WLZ by age in Demographic and Health Surveys and $k i$

685 cohorts

We downloaded standard DHS individual recode files for each country from the DHS program website (https://dhsprogram.com/). We used the most recent standard DHS datasets for the individual women's, household, and length and weight datasets from each country, and we estimated agestratified mean LAZ, WAZ, and WLZ from ages 0 to 24 months within each DHS survey, accounting for the complex survey design and sampling weights. See Benjamin-Chung et. al (2020) for additional details on the DHS data cleaning and analysis. ${ }^{4}$ We compared DHS estimates with mean LAZ, WAZ, and WLZ by age in the $k i$ study cohorts with penalized cubic-splines with bandwidths chosen using generalized crossvalidation. ${ }^{8}$

(a) Spline fits with approximate 95\% simultaneous confidence intervals.

(b)Estimates include children with WLZ measurements within one month before and after that age in the point prevalence estimate, averaging multiple measurements if available for a child. We pooled estimates across studies using random effects models fit with restricted maximum likelihood estimation. Vertical bars indicate $95 \%$ confidence intervals.

(c). We pooled estimates across studies using random effects models fit with restricted maximum likelihood estimation. Vertical bars indicate $95 \%$ confidence intervals. While cumulative incidence cannot decrease over time, the estimated pooled cumulative incidence decreased between the 15-18 month and 18-21 month age bands in the Latin America panel because fewer children were measured between 18-21 months.

(a) Rainfall data was extracted from the University of East Anglia Climate Research Unit CRU TS dataset (version 3.23, 23 October 2015). ${ }^{9}$ Spline fits with approximate 95\% simultaneous confidence intervals are colored by category of seasonal index (high: $\geq$ 0.8 , medium: $<0.8$ and $\geq 0.5$, low: $<0.5$ ) defined by rainfall, and the Walsh and Lawler seasonal index is printed within parentheses next to cohort names. ${ }^{10}$ Higher seasonality indices indicate more heterogeneity in rainfall across months of the year. $\mathrm{Y}$-axis scales vary to best illustrate the seasonal averages for individual cohorts.

(b) Cohort-specific mean differences were estimated using linear regressions, unadjusted for other covariates. Cohort-specific estimates of seasonal differences in WLZ were pooled using random-effects models. ${ }^{10}$ The three-month period opposite the three months of maximum rainfall was used as the reference level (e.g., if JuneAugust was the period of maximum rainfall, the reference level is child mean WLZ during January-March).

(c) Estimates are from children with WLZ measured at birth in South Asian cohorts in both the primary and the inset plot. Shaded region around spline fit indicates its $95 \%$ simultaneous confidence interval. In the inset plot, the estimation of mean differences in WLZ based on month of birth use the same methods as in Panel (b) to estimate cohort-specific difference, then pool using fixed effect models due to data sparsity. January is used as the reference level

Figure 4.

(a) Green intervals mark when the child was not wasted, the yellow interval marks when a child was moderately wasted, and the red interval marks when a child was severely wasted. The age of wasting onset was assumed to occur halfway between a measurement of $W L Z<-2$ and the previous measurement of $W L Z \geq-2$. Recovery from an episode of wasting or severe wasting occurred when a child had 
medRxiv preprint doi: https://doi.org/10.1101/2020.06.09.20126979; this version posted June 11, 2020. The copyright holder for this preprint (which was not certified by peer review) is the author/funder, who has granted medRxiv a license to display the preprint in perpetuity.

It is made available under a CC-BY 4.0 International license .

measurements of $W L Z \geq-2$ for at least 60 days, with the age of recovery assumed to be halfway between the last measurement of $W L Z<-2$ and the first measurement of WLZ $\geq-2$.

(b) Estimates are stratified by child age and geographic region. Wasting incidence was calculated as described in panel (a), and the person-time used in the denominator was determined by the number of days a child was at risk of a new wasting episode (not wasted or in the 60-day recovery period). Incidence rate was estimated by pooling information over cohorts using a random effects estimator; vertical lines indicate $95 \%$ confidence intervals.

(c) Violin plots illustrate the distribution of WLZ in the 3 months following recovery from wasting episodes, with horizontal lines marking the inter-quartile range and annotated with the median WLZ after recovery. Distributions of WLZ after recovery are stratified by age at wasting onset (birth, $0-6 \mathrm{~m}, 6-12 \mathrm{~m}, 12-24 \mathrm{~m}$ ). The horizontal lines within the violins mark the interquartile range, with the median WLZ labeled, and the dashed line marks the $-2 Z$ threshold used to define wasting.

(d) Proportion of children who recovered from a wasting episode within 30,60, and 90 days of episode onset, stratified by region and age at the onset of the wasting episode. Recovery was defined as 2 or more consecutive measures of WLZ $>-2$. Proportions estimated by pooling information over cohorts using a random effects estimator; vertical lines indicate $95 \%$ confidence intervals.

(e) Spline curves of children's WLZ over the first two years of life, stratified by wasting status at birth, show that children born wasted experienced large gains in WLZ in the first four months, but on average their WLZ did not catch up to children not born wasted. Estimates are stratified by wasting status at birth, which includes the first measure of a child within 7 days of birth.

(f) Estimates of cumulative incidence of wasting from 6-24 months, prevalence of cooccurrent wasting and stunting at 18 months, and proportion of children persistently wasted from 6-24 months of age among children born wasted compared to those who were not.

Figure 5.

(a) Estimates were pooled across cohorts using random effects models fit with restricted maximum likelihood estimation. All children who were wasted and stunted were also underweight.

(b) Proportions in each category were calculated within cohorts, pooled using random effects, and scaled so percentages added to $100 \%$.

\section{Sensitivity analyses}

We estimated incidence rates and of wasting after excluding children born or enrolled wasted (Fig. 4b). The rationale for this sensitivity analysis is that incident cases at birth imply a different type of intervention (i.e., prenatal) compared with postnatal onset of wasting. We estimated the overall and region stratified prevalence of persistent wasting and of underweight and severe wasting by age (Extended data fig. 4). We also examined the effect of shorter (30 day) and longer (90) day washout period when determining if a child was again at risk when estimating wasting incidence and wasting recovery rates (Extended data fig. 5). Within cohorts that measured child gestational age at birth, we estimated the prevalence of stunting and underweight at birth both uncorrected and corrected for gestational age at birth using the Intergrowth standards. ${ }^{11}$ Within cohorts that measured middle-upperarm circumference (MUAC), and alternative measurement for classifying wasting than weight-for-length Z-score, we compared wasting prevalence estimated with WLZ and with MUAC. We also re-estimate primary results dropping observations of children at birth within the MRC Keneba cohort, which used a different team to measure child anthropometry at birth from the trained anthropometrists used in follow-up measurements. Lastly, we compared estimates pooled using random effects models, which 
medRxiv preprint doi: https://doi.org/10.1101/2020.06.09.20126979; this version posted June 11, 2020. The copyright holder for this preprint (which was not certified by peer review) is the author/funder, who has granted medRxiv a license to display the preprint in perpetuity.

It is made available under a CC-BY 4.0 International license .

are more conservative in the presence of study heterogeneity, with estimates pooled using fixed effects (inverse variance weighted) models, (results in online supplements at https://child-

787 growth.github.io/wasting).

\section{Data and code availability}

The data that support the findings of this study are available from the Bill and Melinda Gates Foundation Knowledge Integration project upon reasonable request. Replication scripts for this analysis are available here: https://github.com/child-growth/ki-longitudinal-growth.

\section{Methods References}

1. Organization, W. H. \& Fund (UNICEF), U. N. C. Recommendations for data collection, analysis and reporting on anthropometric indicators in children under 5 years old. (World Health Organization, 2019).

2. WHO Multicentre Growth Reference Study Group. WHO child growth standards: length/height-for-age, weight-for-age, weight-for-length, weight-for-height and body mass index-for-age: Methods and development. Geneva World Health Organ. 312 pages (2006).

3. Richard, S. A. et al. Wasting Is Associated with Stunting in Early Childhood123. J. Nutr. 142, 1291-1296 (2012).

802

4. Benjamin-Chung, J. et. al. (submitted). Early childhood linear growth failure in low-and middle-income countries. (2020).

5. Viechtbauer, W. Conducting Meta-Analyses in R with the metafor Package. J. Stat. Softw. 36, 1-48 (2010).

6. Cleveland, W. S. \& Loader, C. Smoothing by Local Regression: Principles and Methods. in Statistical Theory and Computational Aspects of Smoothing (eds. Härdle, W. \& Schimek, M. G.) 10-49 (Physica-Verlag HD, 1996). doi:10.1007/978-3-642-48425-4_2.

7. Ruppert, D., Wand, M. P. \& Carroll, R. J. Semiparametric Regression. (Cambridge University Press, 2003). doi:10.1017/СBO9780511755453.

8. Wood, S. N., Pya, N. \& Säfken, B. Smoothing Parameter and Model Selection for General Smooth Models. J. Am. Stat. Assoc. 111, 1548-1563 (2016).

9. Harris, I., Jones, P. D., Osborn, T. J. \& Lister, D. H. Updated high-resolution grids of monthly climatic observations - the CRU TS3.10 Dataset. Int. J. Climatol. 34, 623-642 (2014).

10. Walsh, R. P. D. \& Lawler, D. M. Rainfall Seasonality: Description, Spatial Patterns and Change Through Time. Weather 36, 201-208 (1981).

11. Papageorghiou, A. T. et al. The INTERGROWTH-21st fetal growth standards: toward the global integration of pregnancy and pediatric care. Am. J. Obstet. Gynecol. 218, S630-S640 (2018). 
medRxiv preprint doi: https://doi.org/10.1101/2020.06.09.20126979; this version posted June 11, 2020. The copyright holder for this preprint (which was not certified by peer review) is the author/funder, who has granted medRxiv a license to display the preprint in perpetuity.

It is made available under a CC-BY 4.0 International license.

\section{Acknowledgments}

830 This research was financially supported by a global development grant (OPP1165144) from the Bill \&

831 Melinda Gates Foundation to the University of California, Berkeley, CA, USA. We would also like to thank

832 the following collaborators on the included cohorts and trials for their contributions to study planning,

833 data collection, and analysis: Muhammad Sharif, Sajjad Kerio, Ms. Urosa, Ms. Alveen, Shahneel Hussain,

834 Vikas Paudel (Mother and Infant Research Activities), Anthony Costello (University College London),

835 Benjamin Torun, Lindsey M Locks, Christine M McDonald, Roland Kupka, Ronald J Bosch, Rodrick

836 Kisenge, Said Aboud, Molin Wang, and all other members of the study staffs and field teams. We would

837 also like to thank all study participants and their families for their important contributions.

838

839 Author contributions

840 Conceptualization: A.M., J.B., J.M.C., K.H.B., P.C., B.F.A

841 Funding Acquisition: J.M.C., A.E.H., M.J.V., B.F.A.

842 Data curation: A.M., J.B., J.C., O.S., W.C., A.N., N.N.P., W.J., E.O.C., S.D., N.H., I.M., H.L., R.H., V.S., J.H.,

843 T.N.

844 Formal analyses: A.M., J.B., J.C., O.S., W.C., A.N., N.N.P., W.J., E.O.C., S.D., N.H., I.M., H.L., V.S., B.F.A

845 Methodology: A.M., J.B., J.M.C, J.C., O.S., N.H., I.M., A.E.H., M.J.V.,K.H.B., P.C., B.F.A.

846 Visualization: A.M.,J.B., A.N., N.N.P., S.D., A.S., J.C., R.H., K.H.B., P.C., B.F.A.

847 Writing - Original Draft Preparation: A.M., J.B., B.F.A.

848 Writing - Review \& Editing: A.M., J.B., J.M.C., K.H.B., P.C., B.F.A., ki Child Growth Consortium members

849

850 Competing interest declaration

851 Thea Norman is an employee of the Bill \& Melinda Gates Foundation (BMGF). Kenneth H Brown and

852 Parul Christian are former employees of BMGF. Jeremy Coyle, Vishak Subramoney, Ryan Hafen, and

853 Jonas Häggström work as research contractors funded by the BMGF.

854

855 Additional information

856 Supplementary Information is available for this paper at https://child-growth.github.io/wasting.

857

858 Correspondence and requests for materials should be addressed to Andrew Mertens

859 (amertens@berkeley.edu) and Benjamin F. Arnold (ben.arnold@ucsf.edu). 
medRxiv preprint doi: https://doi.org/10.1101/2020.06.09.20126979; this version posted June 11, 2020. The copyright holder for this preprint (which was not certified by peer review) is the author/funder, who has granted medRxiv a license to display the preprint in perpetuity.

It is made available under a CC-BY 4.0 International license .

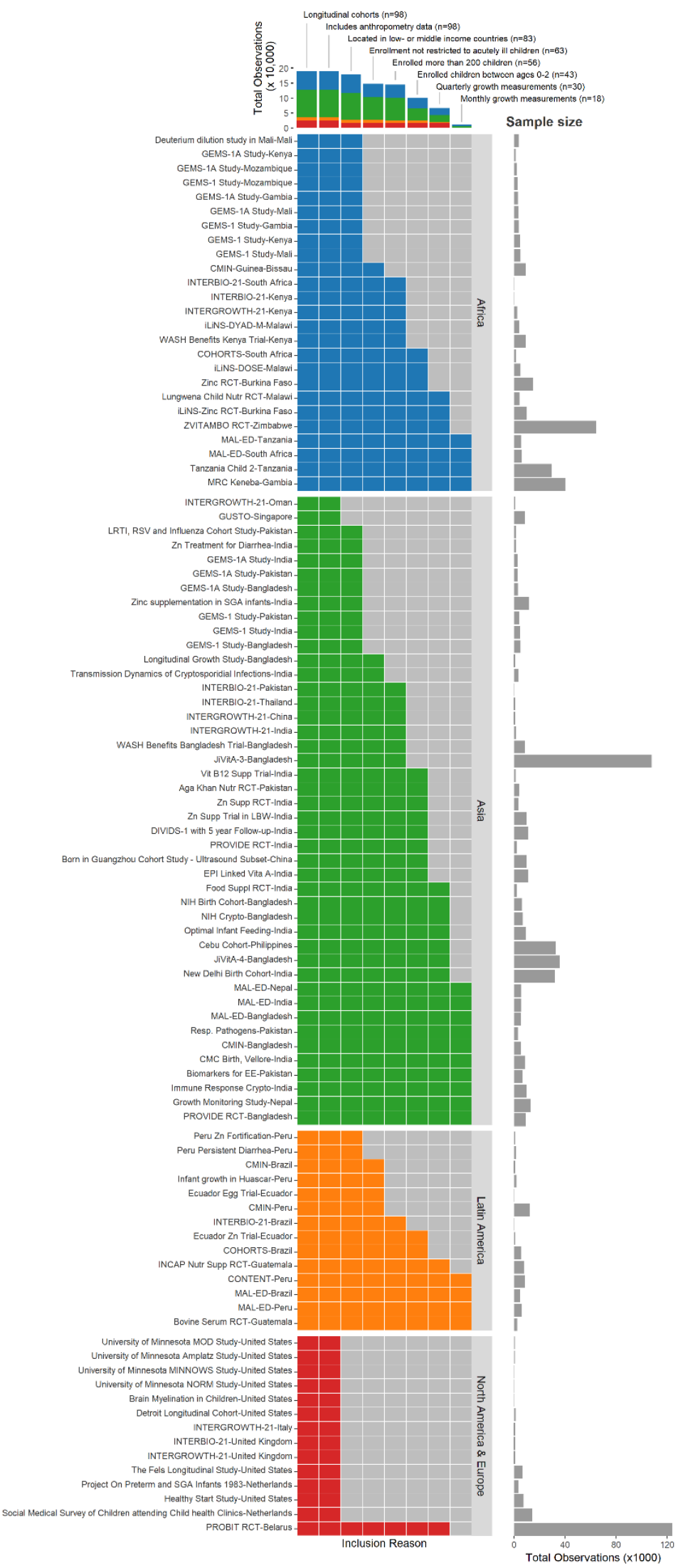


medRxiv preprint doi: https://doi.org/10.1101/2020.06.09.20126979; this version posted June 11, 2020. The copyright holder for this preprint (which was not certified by peer review) is the author/funder, who has granted medRxiv a license to display the preprint in perpetuity.

It is made available under a CC-BY 4.0 International license.

\section{Extended Data Figure 1| ki cohort selection.}

863 Analyses focused on longitudinal cohorts to enable the estimation of prospective incidence rates 864 and growth velocity. On July 15, 2018, there were 86 longitudinal studies on GHAP. From this

865 set, we applied five inclusion criteria to select cohorts for analysis. Our rationale for each

866 criterion follows. (1) Studies were conducted in lower income or middle-income countries. Our

867 target of inference for analyses was children in LMICs, which remains a key target population

868 for preventive interventions. (2) Studies measured length and weight between birth and age 24

869 months. We were principally interested in growth failure during the first two years of life

870 including at birth, thought to be the key window for linear growth failure ${ }^{7}$. (3) Studies did not

871 restrict enrollment to acutely ill children. Our focus on descriptive analyses led us to target, to

872 the extent possible, the general population. We thus excluded some studies that exclusively

873 enrolled acutely ill children, such as children who presented to hospital with acute diarrhea or

874 who were severely malnourished. (4) Studies enrolled at least 200 children. Age-stratified

875 incident episodes of stunting and wasting were sufficiently rare that we wanted to ensure each

876 cohort would have enough information to estimate rates before contributing to pooled estimates.

877 (5) Studies collected anthropometry measurements at least every 3 months. We limited studies

878 to those with higher temporal resolution to ensure that we adequately captured incident

879 episodes and recovery. We further restricted analyses of wasting incidence and recovery to

880 cohorts with monthly measurements because of high temporal variation in WHZ within

881 individuals.

882

883

884

885

886

887

888

889

890

891

892

893

894 


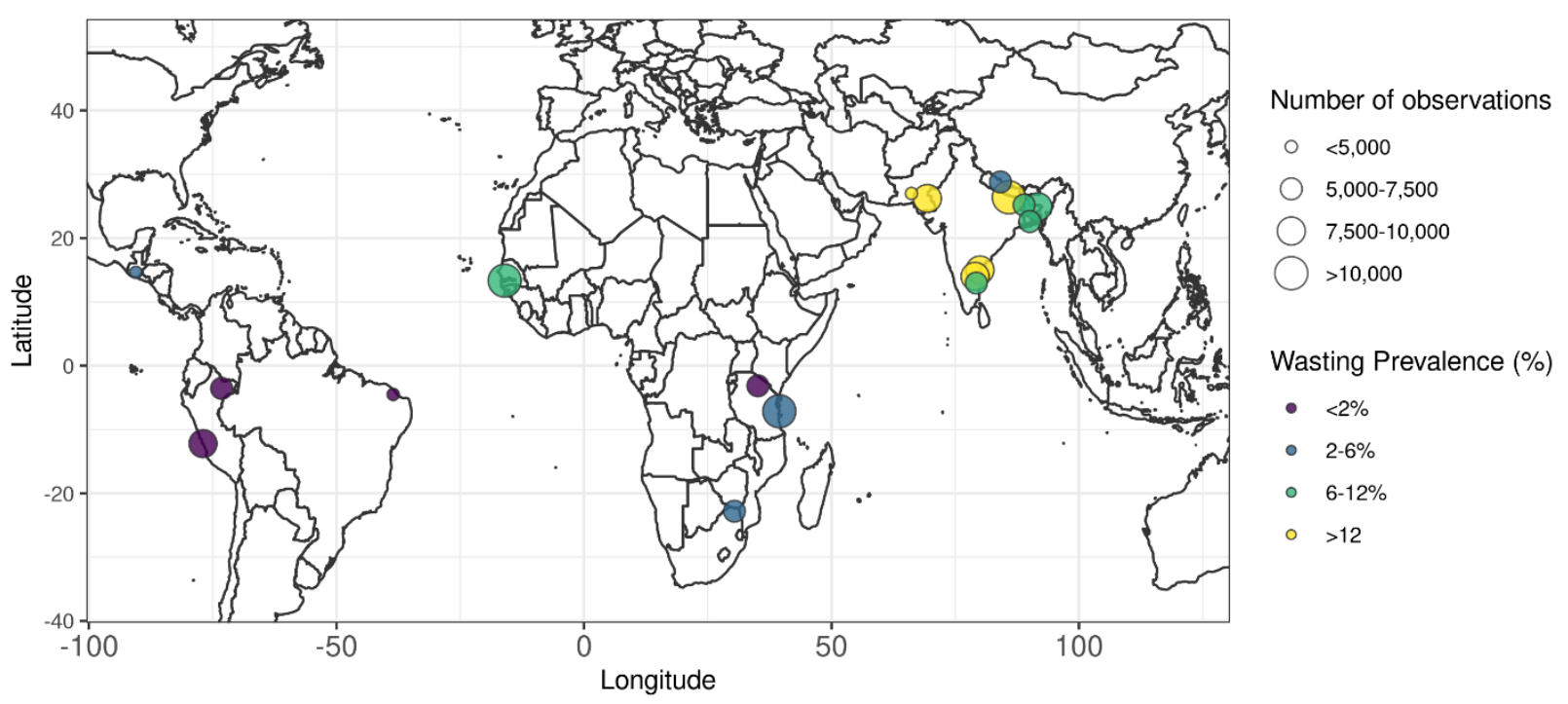

896 approximate and jittered slightly for display. 
medRxiv preprint doi: https://doi.org/10.1101/2020.06.09.20126979; this version posted June 11, 2020. The copyright holder for this preprint (which was not certified by peer review) is the author/funder, who has granted medRxiv a license to display the preprint in perpetuity.

It is made available under a CC-BY 4.0 International license .

910
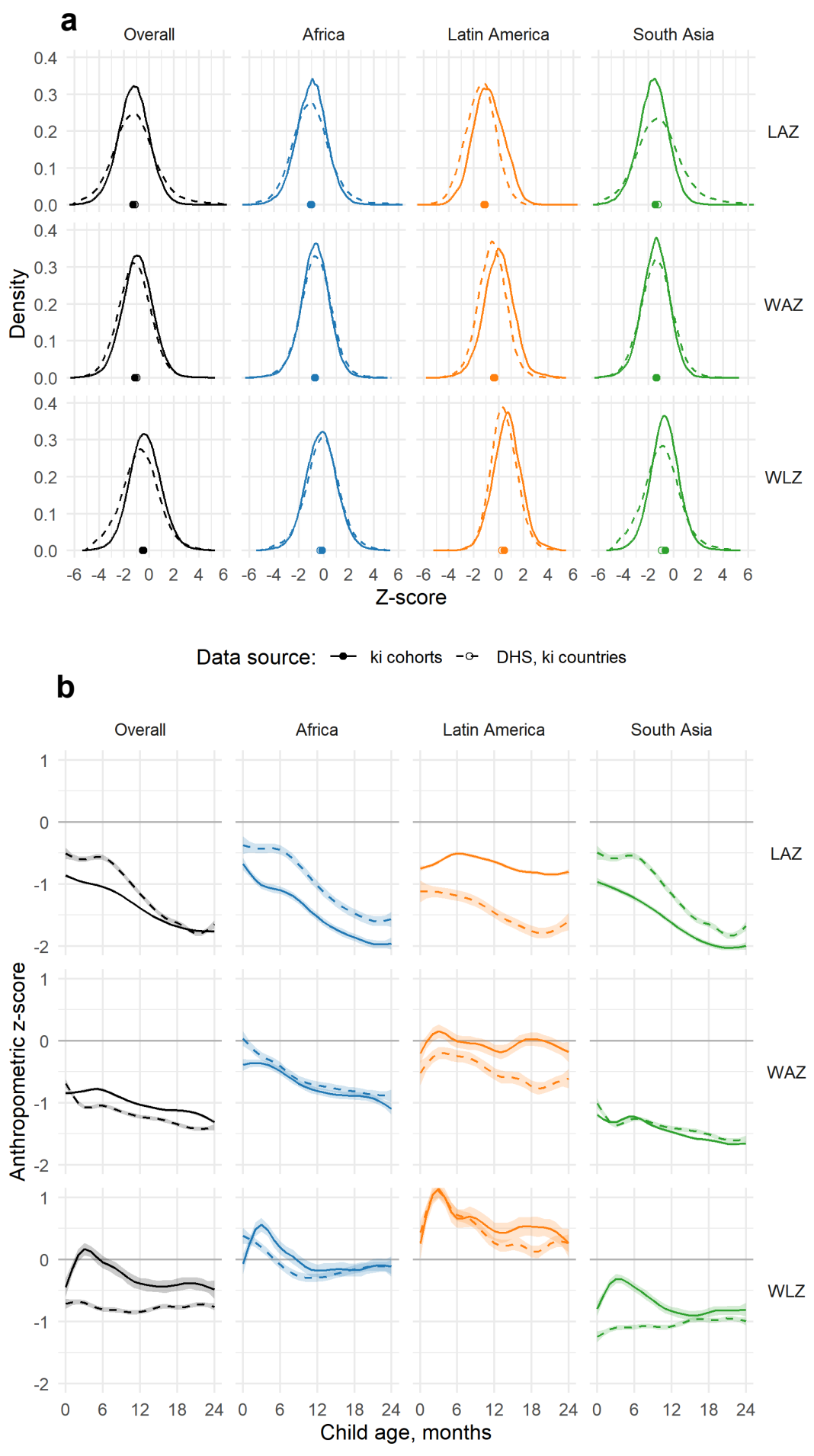

911

Data source: - ki cohorts - - DHS, ki countries

912 Extended Data Figure 3 | Comparison of cohort anthropometry to population-

913 based samples

914 (a) Kernel density distributions of length-for-age (LAZ), weight-for-age (WAZ), and weight-for-

915 length Z-scores (WLZ) from measurements among children under 24 months old in $18 \mathrm{ki}$ 
medRxiv preprint doi: https://doi.org/10.1101/2020.06.09.20126979; this version posted June 11, 2020. The copyright holder for this preprint (which was not certified by peer review) is the author/funder, who has granted medRxiv a license to display the preprint in perpetuity.

It is made available under a CC-BY 4.0 International license.

916 longitudinal cohorts (solid line) and among children measured in population-based,

917 Demographic and Health Surveys (dashed). Estimates stratified by WHO region: AFRO (Africa),

918 SEARO (South East Asia), PAHO (Latin America). DHS estimates include the most recent survey

919 from all countries measured in each WHO region. Overall estimates pool across the three

920 regions.

921 (b) Mean LAZ, WAZ, and WLZ by age among 18 ki longitudinal cohorts (solid line) and in

922 Demographic and Health Surveys (dashed). Means estimated with cubic splines and shaded

923 regions show approximate, simultaneous $95 \%$ credible intervals.

924

925

926

927

928

929

930

931

932

933

934

935

936

937

938

939

940

941

942

943

944

945 
medRxiv preprint doi: https://doi.org/10.1101/2020.06.09.20126979; this version posted June 11, 2020. The copyright holder for this preprint (which was not certified by peer review) is the author/funder, who has granted medRxiv a license to display the preprint in perpetuity.

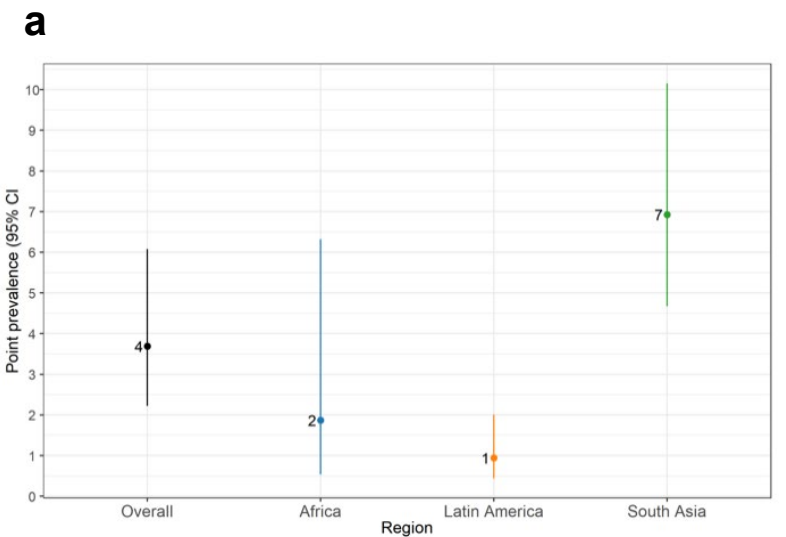

948

b
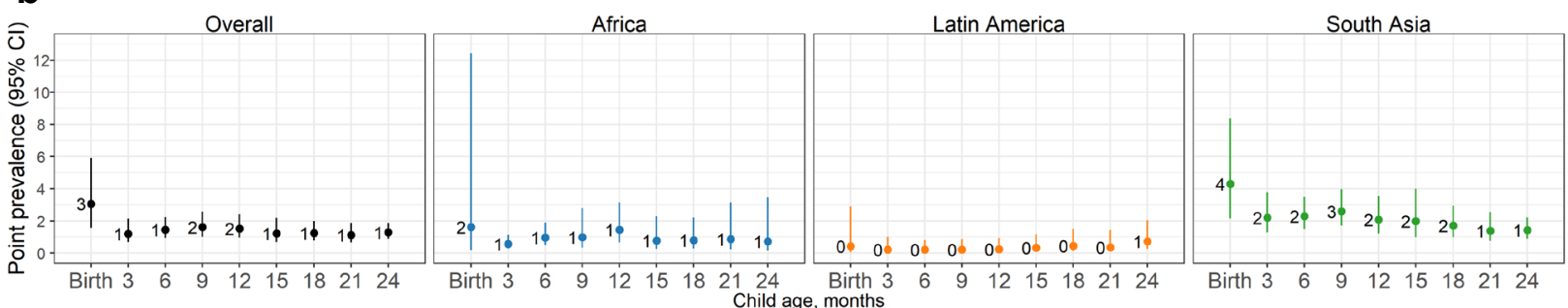

C
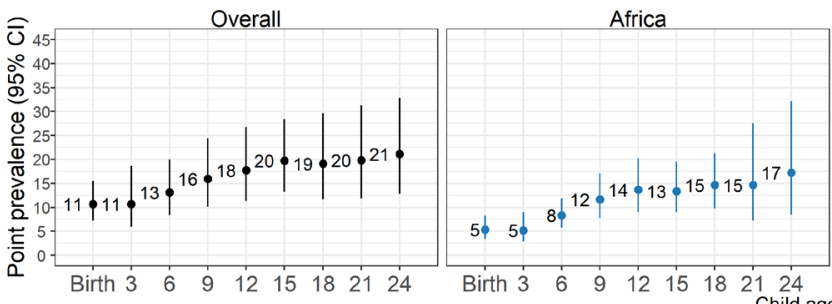

Latin America

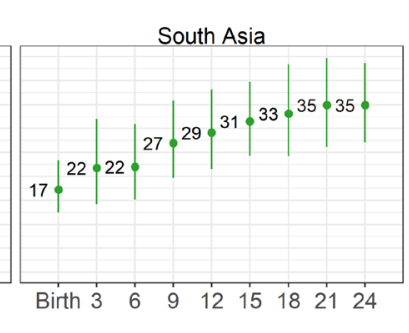

950

Extended Data Figure 4 | Prevalence of persistent wasting, severe wasting, and underweight by region.

953 (a) Proportion of children persistently wasted ( $\geq 50 \%$ of measurements from birth to 24 months of age,

954 overall and stratified by region.

955 (b) Prevalence of severe wasting (WLZ <-3) by age and region.

956 (c) Prevalence of underweight (weight-for-age Z-score <-2) by age and region.

957

958

959 
medRxiv preprint doi: https://doi.org/10.1101/2020.06.09.20126979; this version posted June 11, 2020. The copyright holder for this preprint (which was not certified by peer review) is the author/funder, who has granted medRxiv a license to display the preprint in perpetuity.

It is made available under a CC-BY 4.0 International license .
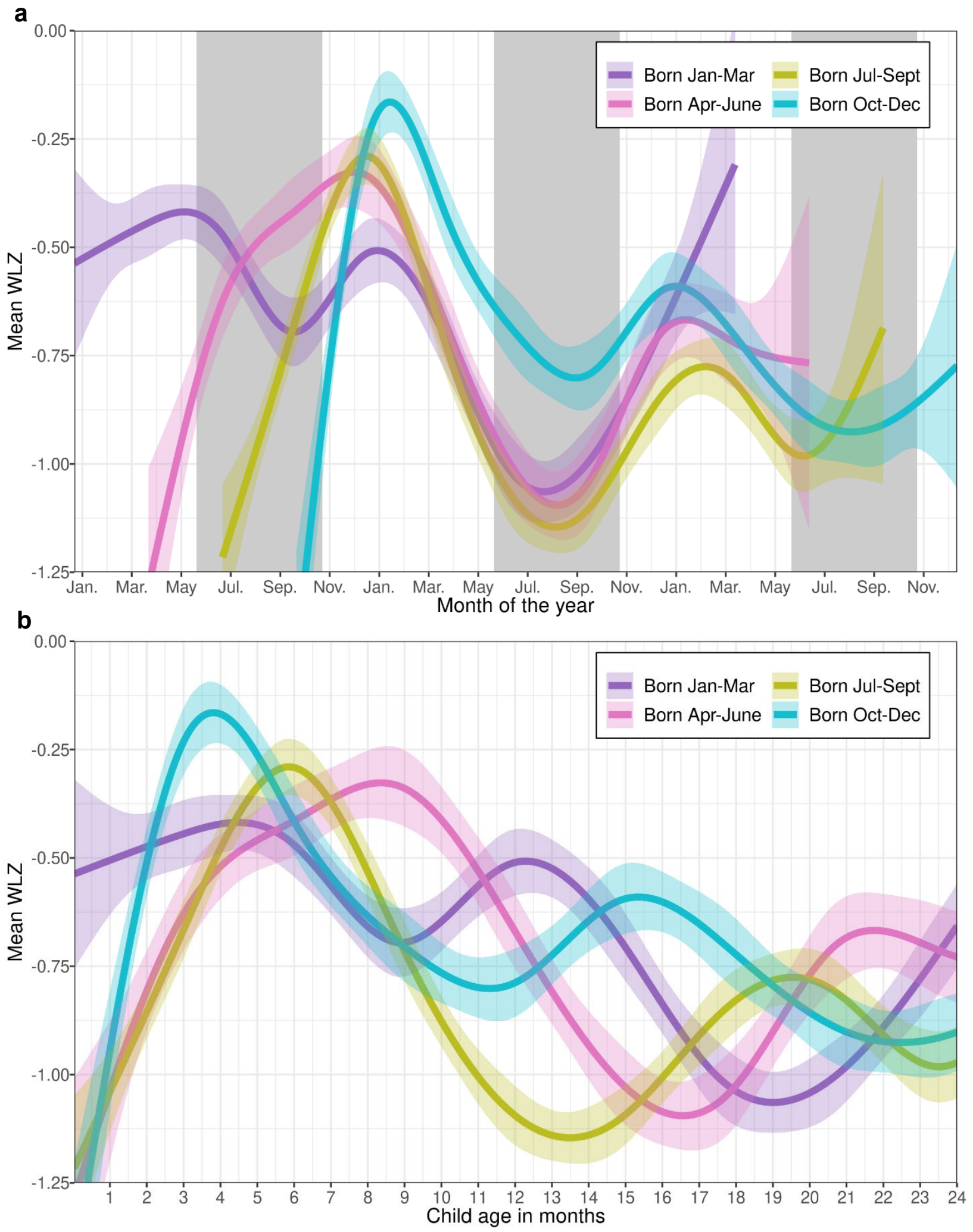

(a) Mean WLZ by calendar month among South Asian cohorts, with children stratified by birth month. The indicate the approximate timing of seasonal monsoons in South Asia (June-September) Shaded regions 
medRxiv preprint doi: https://doi.org/10.1101/2020.06.09.20126979; this version posted June 11, 2020. The copyright holder for this preprint (which was not certified by peer review) is the author/funder, who has granted medRxiv a license to display the preprint in perpetuity.

It is made available under a CC-BY 4.0 International license .

966 around spline fits indicate 95\% simultaneous confidence intervals. Ten cohorts, 3,880 children, and

96775,371 measurements were used to estimate the splines. South Asian children born in July-September

968 had the lowest mean WLZ overall and children born April-September had larger seasonal declines in

969 WLZ during their second year of life than children born October-March.

970 (b) Mean WLZ from birth to age 24 months among children from South Asian cohorts stratified by birth

971 month. Shaded regions around spline fits indicate $95 \%$ simultaneous confidence intervals. Data used is

972 the same as in panel (a).

973

974

975

976

977

978

979

980

981

982

983

984

985

986 
medRxiv preprint doi: https://doi.org/10.1101/2020.06.09.20126979; this version posted June 11, 2020. The copyright holder for this preprint (which was not certified by peer review) is the author/funder, who has granted medRxiv a license to display the preprint in perpetuity.

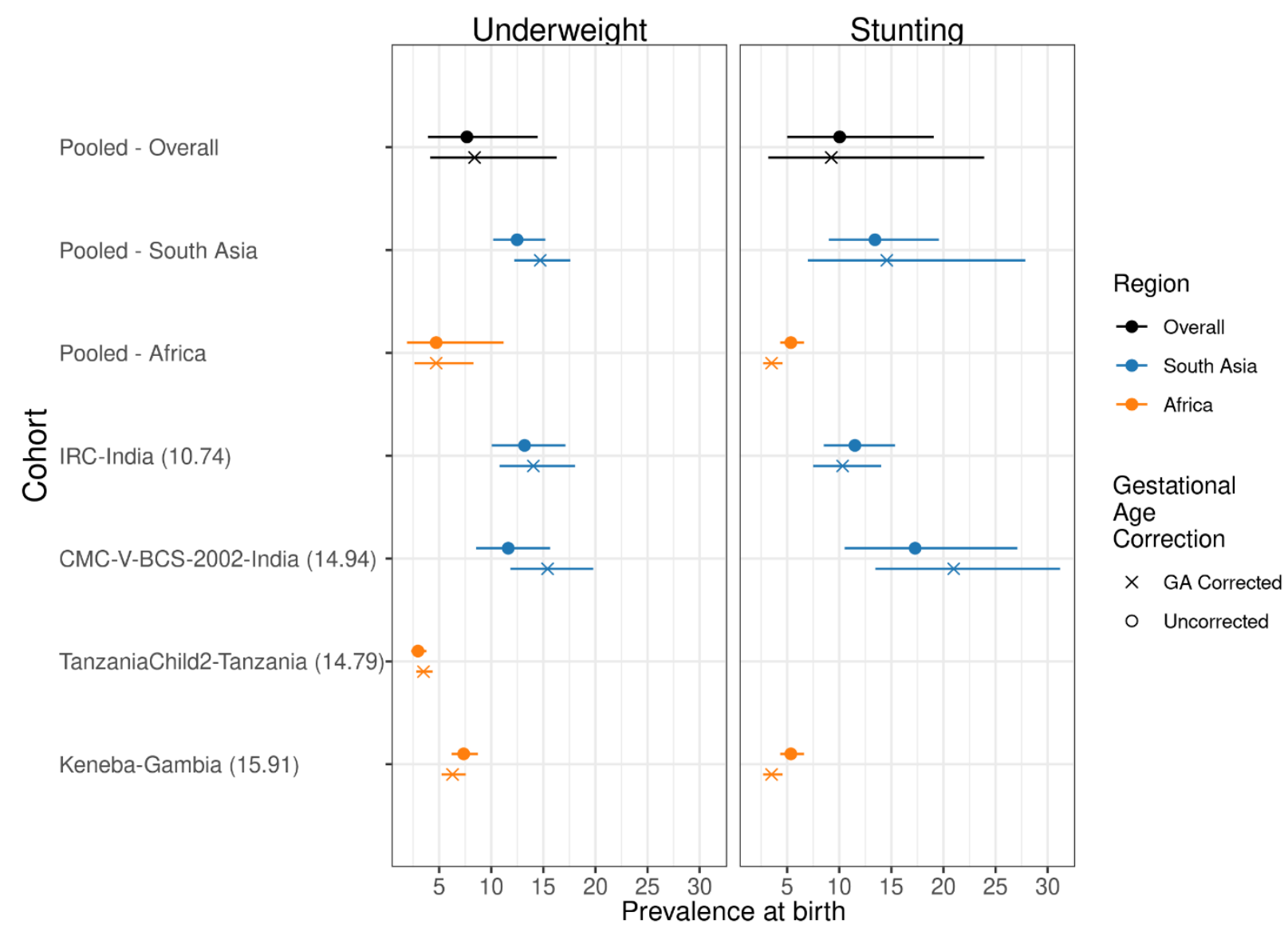

988 Extended Data Figure 6 | Comparison of underweight and stunting prevalence at birth 989 with and without gestational age correction

990 This figure includes the results from correcting at-birth Z-scores in the $k i$ cohorts that measured gestational age (GA). The corrections are using the Intergrowth standards and are implemented using the R growthstandards package (https://ki-tools.github.io/growthstandards/). Overall, the prevalence at birth decreased slightly after correcting for gestational age, but the cohort-specific results are inconsistent. Observations with GA outside of the Intergrowth standards range (<168 or $>300$ days) were dropped for both the corrected and uncorrected data. Prevalence increased after GA correction in some cohorts due to high rates of late-term births based on reported GA. There were no length measurements at birth in the Tanzania Child 2 cohort, so they do not have stunting estimates. There were 4,445 measurements used in the underweight analysis and 1,931 measurements used in the stunting analysis. Gestational age was estimates based on mother's recall of the last menstrual period in the IRC, CMC-V-BCS-2002, and Tanzania Child cohorts, and was based on the Dubowitz method (newborn exam) in the MRC Keneba cohort. 
medRxiv preprint doi: https://doi.org/10.1101/2020.06.09.20126979; this version posted June 11, 2020. The copyright holder for this preprint (which was not certified by peer review) is the author/funder, who has granted medRxiv a license to display the preprint in perpetuity.

It is made available under a CC-BY 4.0 International license .

1009 Extended Data Table 1/ Summary of ki cohorts

\begin{tabular}{|c|c|c|c|c|c|c|c|}
\hline $\begin{array}{l}\text { Region, } \\
\text { Study ID }\end{array}$ & $\begin{array}{l}\text { Count } \\
\text { ry }\end{array}$ & $\begin{array}{l}\text { Study } \\
\text { Years }\end{array}$ & Design & $\begin{array}{l}\text { Children } \\
\text { Enrolled* }\end{array}$ & $\begin{array}{l}\text { Anthropometry } \\
\text { measurement ages } \\
\text { (months) }\end{array}$ & $\begin{array}{l}\text { Total } \\
\text { measurem } \\
\text { ents }^{*} \\
\end{array}$ & Primary References \\
\hline \multicolumn{8}{|l|}{ South Asia } \\
\hline $\begin{array}{l}\text { Biomarkers } \\
\text { for EE }\end{array}$ & $\begin{array}{l}\text { Pakist } \\
\text { an }\end{array}$ & $\begin{array}{l}2013- \\
2015\end{array}$ & $\begin{array}{l}\text { Prospecti } \\
\text { ve cohort }\end{array}$ & 380 & Birth, $1,2, \ldots, 18$ & 8428 & $\begin{array}{l}\text { lqbal et al } 2018 \\
\text { Nature Scientific } \\
\text { Reports }^{1}\end{array}$ \\
\hline $\begin{array}{l}\text { Resp. } \\
\text { Pathogens }\end{array}$ & $\begin{array}{l}\text { Pakist } \\
\text { an }\end{array}$ & $\begin{array}{l}2011- \\
2014\end{array}$ & $\begin{array}{l}\text { Prospecti } \\
\text { ve cohort }\end{array}$ & 284 & Birth, $1,2, \ldots, 17$ & 3164 & $\begin{array}{l}\text { Ali et al } 2016 \text { Journal } \\
\text { of Medical Virology }\end{array}$ \\
\hline $\begin{array}{l}\text { Growth } \\
\text { Monitoring } \\
\text { Study }\end{array}$ & Nepal & $\begin{array}{l}2012- \\
\text { Ongoin } \\
\mathrm{g}\end{array}$ & $\begin{array}{l}\text { Prospecti } \\
\text { ve cohort }\end{array}$ & 686 & Birth, 1, 2, .., 24 & 13340 & Not yet published \\
\hline MAL-ED & Nepal & $\begin{array}{l}2010- \\
2014\end{array}$ & $\begin{array}{l}\text { Prospecti } \\
\text { ve cohort }\end{array}$ & 240 & Birth, 1, 2, .., 24 & 5695 & $\begin{array}{l}\text { Shrestha et al } 2014 \\
\text { Clin Infect Dis } \\
\end{array}$ \\
\hline $\begin{array}{l}\text { CMC Birth } \\
\text { Cohort, } \\
\text { Vellore }\end{array}$ & India & $\begin{array}{l}2002- \\
2006\end{array}$ & $\begin{array}{l}\text { Prospecti } \\
\text { ve cohort }\end{array}$ & 373 & Birth, $0.5,1,1.5, \ldots, 24$ & 8697 & $\begin{array}{l}\text { Gladstone et al. } 2011 \\
\text { NEJM }^{4}\end{array}$ \\
\hline MAL-ED & India & $\begin{array}{l}2010- \\
2012 \\
\end{array}$ & $\begin{array}{l}\text { Prospecti } \\
\text { ve cohort }\end{array}$ & 251 & Birth, 1, 2, .., 24 & 5697 & $\begin{array}{l}\text { John et al } 2014 \text { Clin } \\
\text { Infect Dis }^{5}\end{array}$ \\
\hline $\begin{array}{l}\text { Vellore } \\
\text { Crypto Study }\end{array}$ & India & $\begin{array}{l}2008- \\
2011 \\
\end{array}$ & $\begin{array}{l}\text { Prospecti } \\
\text { ve cohort } \\
\end{array}$ & 410 & Birth, 1, 2, .., 24 & 9729 & $\begin{array}{l}\text { Kattula et al. } 2014 \\
\text { BMJ Open }\end{array}$ \\
\hline CMIN & $\begin{array}{l}\text { Bangl } \\
\text { adesh }\end{array}$ & $\begin{array}{l}1993- \\
1996 \\
\end{array}$ & $\begin{array}{l}\text { Prospecti } \\
\text { ve Cohort }\end{array}$ & 272 & Birth, 3, 6, .., 24 & 5372 & $\begin{array}{l}\text { Pathela et al } 2007 \\
\text { Acta Paediatrica }^{7}\end{array}$ \\
\hline MAL-ED & $\begin{array}{l}\text { Bangl } \\
\text { adesh }\end{array}$ & $\begin{array}{l}2010- \\
2014\end{array}$ & $\begin{array}{l}\text { Prospecti } \\
\text { ve cohort }\end{array}$ & 263 & Birth, $1,2, \ldots, 24$ & 5592 & $\begin{array}{l}\text { Ahmed et al } 2014 \\
\text { Clin Infect Dis }\end{array}$ \\
\hline $\begin{array}{l}\text { PROVIDE } \\
\text { RCT }\end{array}$ & $\begin{array}{l}\text { Bangl } \\
\text { adesh }\end{array}$ & $\begin{array}{l}2011- \\
2014\end{array}$ & $\begin{array}{l}\text { Individual } \\
\text { RCT }\end{array}$ & 700 & $\begin{array}{l}\text { Birth, 6, 10, 12, 14. 17, 18, } \\
24,39,40,52,53 \text { (weeks) }\end{array}$ & 9202 & $\begin{array}{l}\text { Kirkpatrick et al } 2015 \\
\text { Am J Trop Med Hyg }\end{array}$ \\
\hline \multicolumn{8}{|l|}{ Africa } \\
\hline MAL-ED & $\begin{array}{l}\text { Tanza } \\
\text { nia }\end{array}$ & $\begin{array}{l}2009- \\
2014 \\
\end{array}$ & $\begin{array}{l}\text { Prospecti } \\
\text { ve cohort }\end{array}$ & 261 & Birth, 1, 2, .., 24 & 5698 & $\begin{array}{l}\text { Mduma et al } 2014 \\
\text { Clin Infect Dis }{ }^{10}\end{array}$ \\
\hline $\begin{array}{l}\text { Tanzania } \\
\text { Child } 2 \\
\end{array}$ & $\begin{array}{l}\text { Tanza } \\
\text { nia }\end{array}$ & $\begin{array}{l}2007- \\
2011 \\
\end{array}$ & $\begin{array}{l}\text { Individual } \\
\text { RCT }\end{array}$ & 2396 & $1,2, \ldots, 20$ & 29518 & $\begin{array}{l}\text { Locks et al Am J Clin } \\
\text { Nutr } 2016^{11}\end{array}$ \\
\hline MAL-ED & $\begin{array}{l}\text { South } \\
\text { Africa }\end{array}$ & $\begin{array}{l}2009- \\
2014 \\
\end{array}$ & $\begin{array}{l}\text { Prospecti } \\
\text { ve cohort }\end{array}$ & 312 & Birth, 1, 2, .., 24 & 6151 & $\begin{array}{l}\text { Bessong et al } 2014 \\
\text { Clin Infect Dis }{ }^{12}\end{array}$ \\
\hline $\begin{array}{l}\text { MRC } \\
\text { Keneba }\end{array}$ & $\begin{array}{l}\text { Gamb } \\
\text { ia }\end{array}$ & $\begin{array}{l}1987- \\
1997 \\
\end{array}$ & Cohort & 2920 & Birth, $1,2, \ldots, 24$ & 40117 & $\begin{array}{l}\text { Schoenbuchner et al. } \\
2019, \mathrm{AJCN}^{13}\end{array}$ \\
\hline \multicolumn{8}{|l|}{ Latin America } \\
\hline MAL-ED & Peru & $\begin{array}{l}2009- \\
2014\end{array}$ & $\begin{array}{l}\text { Prospecti } \\
\text { ve cohort }\end{array}$ & 302 & Birth, 1, 2, .., 24 & 6127 & $\begin{array}{l}\text { Yori et al } 2014 \text { Clin } \\
\text { Infect Dis }\end{array}$ \\
\hline CONTENT & Peru & $\begin{array}{l}2007- \\
2011\end{array}$ & $\begin{array}{l}\text { Prospecti } \\
\text { ve cohort }\end{array}$ & 215 & Birth, 1, 2, .., 24 & 8339 & $\begin{array}{l}\text { Jaganath et al } 2014 \\
\text { Helicobacter }^{15}\end{array}$ \\
\hline $\begin{array}{l}\text { Bovine } \\
\text { Serum RCT }\end{array}$ & $\begin{array}{l}\text { Guate } \\
\text { mala }\end{array}$ & $\begin{array}{l}1997- \\
1998 \\
\end{array}$ & $\begin{array}{l}\text { Individual } \\
\text { RCT }\end{array}$ & 315 & Baseline, $1,2, \ldots, 8$ & 2545 & $\begin{array}{l}\text { Begin et al. 2008, } \\
\text { EJCN }^{16}\end{array}$ \\
\hline MAL-ED & Brazil & $\begin{array}{l}2010- \\
2014 \\
\end{array}$ & $\begin{array}{l}\text { Prospecti } \\
\text { ve cohort }\end{array}$ & 233 & Birth, 1, 2, .., 24 & 4838 & $\begin{array}{l}\text { Lima et al } 2014 \text { Clin } \\
\text { Infect Dis }{ }^{17}\end{array}$ \\
\hline
\end{tabular}


medRxiv preprint doi: https://doi.org/10.1101/2020.06.09.20126979; this version posted June 11, 2020. The copyright holder for this preprint (which was not certified by peer review) is the author/funder, who has granted medRxiv a license to display the preprint in perpetuity.

It is made available under a CC-BY 4.0 International license .

\section{Supplementary References}

1. Iqbal, N. T. et al. Promising Biomarkers of Environmental Enteric Dysfunction: A Prospective Cohort study in Pakistani Children. Sci. Rep. 8, 2966 (2018).

2. Ali, A. et al. Respiratory viruses associated with severe pneumonia in children under 2 years old in a rural community in Pakistan. J. Med. Virol. 88, 1882-1890 (2016).

3. Shrestha, P. S. et al. Bhaktapur, Nepal: The MAL-ED Birth Cohort Study in Nepal. Clin. Infect. Dis. 59, S300-S303 (2014).

4. Gladstone, B. P. et al. Protective Effect of Natural Rotavirus Infection in an Indian Birth Cohort. N. Engl. J. Med. 365, 337-346 (2011).

5. John, S. M. et al. Establishment of the MAL-ED Birth Cohort Study Site in Vellore, Southern India. Clin. Infect. Dis. 59, S295-S299 (2014).

6. Kattula, D. et al. The first 1000 days of life: prenatal and postnatal risk factors for morbidity and growth in a birth cohort in southern India. BMJ Open 4, e005404 (2014).

7. Pathela, P. et al. Diarrheal illness in a cohort of children 0-2 years of age in rural Bangladesh: I. Incidence and risk factors: Risk factors for diarrhea in Bangladeshi children. Acta Paediatr. 95, 430437 (2007).

8. Ahmed, T. et al. The MAL-ED Cohort Study in Mirpur, Bangladesh. Clin. Infect. Dis. 59, S280-S286 (2014).

9. Kirkpatrick, B. D. et al. The "Performance of Rotavirus and Oral Polio Vaccines in Developing Countries" (PROVIDE) Study: Description of Methods of an Interventional Study Designed to Explore Complex Biologic Problems. Am. J. Trop. Med. Hyg. 92, 744-751 (2015).

10. Mduma, E. R. et al. The Etiology, Risk Factors, and Interactions of Enteric Infections and Malnutrition and the Consequences for Child Health and Development Study (MAL-ED): Description of the Tanzanian Site. Clin. Infect. Dis. 59, S325-S330 (2014).

11. Locks, L. M. et al. Effect of zinc and multivitamin supplementation on the growth of Tanzanian children aged 6-84 wk: a randomized, placebo-controlled, double-blind trial12. Am. J. Clin. Nutr. 103, 910-918 (2016).

12. Bessong, P. O., Nyathi, E., Mahopo, T. C. \& Netshandama, V. Development of the Dzimauli Community in Vhembe District, Limpopo Province of South Africa, for the MAL-ED Cohort Study. Clin. Infect. Dis. 59, S317-S324 (2014).

13. Schoenbuchner, S. M. et al. The relationship between wasting and stunting: a retrospective cohort analysis of longitudinal data in Gambian children from 1976 to 2016. Am. J. Clin. Nutr. doi:10.1093/ajcn/nqy326.

14. Yori, P. P. et al. Santa Clara de Nanay: The MAL-ED Cohort in Peru. Clin. Infect. Dis. 59, S310-S316 (2014).

15. Jaganath, D. et al. First Detected Helicobacter pylori Infection in Infancy Modifies the Association Between Diarrheal Disease and Childhood Growth in Peru. Helicobacter 19, 272-279 (2014).

16. Bégin, F., Santizo, M.-C., Peerson, J. M., Torún, B. \& Brown, K. H. Effects of bovine serum concentrate, with or without supplemental micronutrients, on the growth, morbidity, and micronutrient status of young children in a low-income, peri-urban Guatemalan community. Eur. J. Clin. Nutr. 62, 39-50 (2008).

17. Lima, A. A. M. et al. Geography, Population, Demography, Socioeconomic, Anthropometry, and Environmental Status in the MAL-ED Cohort and Case-Control Study Sites in Fortaleza, Ceará, Brazil. Clin. Infect. Dis. 59, S287-S294 (2014). 